\title{
MARCO VENTURA*
}

\section{THE FORMULA 'FREEDOM OF RELIGION OR BELIEF' IN THE LABORATORY OF THE EUROPEAN UNION}

\begin{abstract}
This article argues that more and better knowledge about the past and present of the formula 'freedom of religion or belief' is likely to result in a stronger consistency between the terminology and the concept, while being conducive to a richer national and international conversation on the protection and promotion of 'religion or belief' related rights and freedoms. In the first section (The emergence) the author maps the chronology and context of the emergence of the formula: while confirming the importance of the United Nations, it is emphasized that UN documents were not alone, and were not in isolation. In particular, the importance of the Conference, then Organisation for Security and Cooperation in Europe, and of a general international conversation, accelerated by the adoption in 1998 of the US International Religious Freedom Act, is underlined. In the second
\end{abstract}

This article has been produced in the context of 'REREDIEU. Representing Religious Diversity in Europe: Past and Present \& Features', a research project funded by the Italian Ministry of Research under the PRIN 2017 action. The project is a joint initiative of the University of Modena and Reggio Emilia, the University of Siena and Consiglio Nazionale delle Ricerche CNR. The article benefits from comments, insights and inputs by Silvia Angeletti, W. Cole Durham Jr., Daniele Ferrari, Frederick Mark Gedicks, T. Jeremy Gunn and Riccardo Pavoni. I am very grateful to all of them. Of course, the views, thoughts and opinions expressed in the text, as well as errors and omissions belong solely to the author.

* $\quad \mathrm{PhD}$ Strasbourg, Professor of Law and Religion at the University of Siena; via Mattioli, 10, 53100 Siena, Italy; e-mail: marco.ventura@unisi.it. ORCID: 0000-0002-2007-6649. Director of the Centre for Religious Studies at Fondazione Bruno Kessler of Trento. Associate researcher of DRES, Center for Droit, Religion, Entreprise et Société, University of Strasbourg. Member of the OSCE/ODIHR Panel of Experts on Freedom of Religion or Belief. 
section (The features) the most significant features of the formula are identified, and it is suggested that those features should be taken as the reasons why in the last two decades the formula has proved successful at the UN and OSCE level, as well as in the context of the European Union, mainly in its external action. In the third section (The EU laboratory) the formula is mapped in the EU context and the EU framework is interpreted as a laboratory where the formula is received, challenged and reinvented in a variety of ways. In the fourth and final session (The translation) ten sets of questions are offered with respect to the linguistic and legal translation of the formula in EU Member States. If addressed, it is held, those questions might considerably improve knowledge on the formula in both its top-down and bottom-up dynamic unfolding, thus empowering scholars and actors engaged with combining the global power of the formula in English and its variations in different languages and cultures.

Key words: freedom of religion or belief; Church and State; law and religion; European Union Law; international human rights law

$* * * * *$

\section{INTRODUCTION}

In the opening sentence of its 2013 'Guidelines on the promotion and protection of freedom of religion or belief', the European Union states that 'the right to freedom of thought, conscience, religion or belief' is 'more commonly referred to as the right to freedom of religion or belief (FoRB)'. 'Through this statement, and the very title of the 2013 EU Guidelines, the European Union acknowledges and endorses the emergence of the expression 'freedom of religion or belief (FoRB)' as the most common formula used in the international exchange on the subject.

As seemingly indicated in the text of the 2013 EU Guidelines, one might infer that the emergence of the 'freedom of religion or belief' formula and the FoRB acronym has no other reason than the need for

1 EU Council, EU Guidelines on the promotion and protection of freedom of religion or belief, 24 June 2013 (https://www.consilium.europa.eu/uedocs/cms_data/docs/pressdata/ EN/foraff/137585.pdf; last visited 1 July 2020). 
an increasingly wide and diverse public of scholars and actors to conventionally adopt the same expression for the sake of a better protection and promotion of the relevant rights and freedoms. Responding to such a need, the formula presents the double advantage of 1) being close to the terminology used in international human rights documents, where 'religion' and 'belief' have been regularly employed since 1948, and 2) being shorter, and therefore more practical, than the fourfold reference in official texts to thought, conscience, religion and belief as domains worth of protection through fundamental rights and freedoms. In this sense, the formula is assumed 1) to be neutrally derived from international sources, non-binding (e.g., the Universal Declaration of Human Rights of 1948) as well as binding (e.g., the International Covenant on Civil and Political Rights of 1966), and 2) to be basically interchangeable with others, most typically with 'religious freedom', unless the latter is deliberately mobilised in order to prioritise religious beliefs over non-religious beliefs, and even certain religions over others. The two assumptions combine in definitions of the formula 'freedom of religion or belief' as fundamentally equivalent to 'religious freedom', and yet more inclusive because of the additional reference to belief, and more accurate insofar as that addition reflects better the original text and mandate of international human rights documents. This approach is becoming very common in Western Europe, and in certain sectors of Anglo-Saxon, and English-speaking advocacy and scholarship. It is at work, for instance, when the formula is presented in the Report on the international protection of FoRB issued in 2019 by the Danish Institute for Human Rights in the following terms: 'This report uses the term «freedom of religion or belief», the standard term used in international human rights documents. Especially in the US, and in much literature, «religious freedom»

2 International Promotion of Freedom of Religion or Belief. Sketching the Contours of a Common Framework. The Report was authored by Marie Juul Petersen and Katherine Marshall and produced in partnership with the Berkley Center at Georgetown University (see Peterson, and Marshall 2019). The Report was based on a study commissioned by the Special Representative for Freedom of Religion or Belief of the Danish Ministry of Foreign Affairs. The text is available at https:/www.humanrights.dk/sites/humanrights.dk/ files/media/dokumenter/udgivelser/research/2019/rapport_internationalpromotion_12.pdf (last visited 1 July 2020). 
is more common. Religious freedom is sometimes used interchangeably with FoRB, but tends to indicate a focus on the rights of religious individuals and groups, versus a broad conception of freedom of religion or belief for all, including non-believers'. ${ }^{3}$

Scholars and actors have worked at length on global restrictions on 'religion or belief' resulting from government measures and social hostility, according to the categorisation offered since 2007 by the US-based Pew Research Center. ${ }^{4}$ Researchers at the Pew Research Center have been a very influential data provider nourishing the alarm and mobilisation on increasing global restrictions on 'religion or belief', although they abstain from resorting to the formula 'freedom of religion or belief', or even to the expression 'religion or belief', as they rather adopt terms such as 'religious restrictions' and 'religious freedom'. Scholars and actors have also provided thorough research on the law and policy system of protection and promotion of 'freedom of religion or belief'. Still, no in-depth, systematic investigation on the formula itself seems to be available. The 2016 international law commentary on 'Freedom of Religion or Belief' by Heiner Bielefeldt, Nazila Ghanea and Michael Wiener is a masterful monument of scholarship on the subject under a title promoting that very formula, and yet it does not devote one line of its 600 pages to the formula as such. ${ }^{5}$

As experts and actors employ formulas, and resort to formulaic language, they are particularly well placed to be aware of the performative power of language in general, and in particular of legal formulas such as 'freedom of religion or belief (FoRB)'. The ritual dimension of the law is at stake here. As Italian legal philosopher Mariano Croce holds, 'ritual in law plays two intertwined and yet conflicting functions, conservative and

Ibid., 95 (note 1).

4 I refer in particular to the tenth annual Report published in July 2019 under the title: A Closer Look at How Religious Restrictions Have Risen Around the World (https://www. pewforum.org/2019/07/15/a-closer-look-at-how-religious-restrictions-have-risen-aroundthe-world/; last visited 1 July 2020).

5 I refer to Bielefeldt, Ghanea, and Wiener 2016. The Commentary elaborates at length about the right and freedom the formula is expected to protect and promote. Two of the three authors have further expanded and refined their analysis in Bielefeldt, and Wiener 2019. 
transformative, which make law be at one and the same time the producer of social «normality» and the field in which this very normality can be questioned and revised'. ${ }^{6}$ Similarly, those who employ the formula 'freedom of religion or belief' cannot be too specific as they need to let it operate with some degree of autonomy enabling users' creativity in order for its ritual force to unfold in both the 'conservative and transformative' functions. Croce understands the ritual in the law according to Roy Rappaport's theory of the ritual. For the American anthropologist the ritual is not limited to religion and it demands, as Croce puts it, that 'performers do not entirely encode their acts and utterances because they do not specify all the acts and utterances that comprise their own performances'. ${ }^{7}$ In his legal investigation on the relation between word and world, Mariano Croce further points at British linguist J. L. Austin as the first author to identify 'the kind of utterances which are not meant to describe anything, but to perform an action while it is being uttered'. ${ }^{8}$ If we take this dimension into account, we fully appreciate the power of the formula, beyond its particular definition, since, as Croce explains, "not only does ritual ensure the correctness of the speech act performed in it, but also makes its performative force explicit and stronger'.

The performative quality of the formula 'freedom of religion or belief' is perfectly illustrated by its definition in the above-mentioned Danish Re-

6 Croce 2012, 149. The author further explains: 'On the one hand, ritual makes law obtain and preserve its separation from everyday life in order for what is said or done by the parties within the legal field to obtain a special and weighty value. This is the conservative function, played by law's nondiscursive dimension, in which the possible types of relationships among the members of a given geo-historical context are defined and, accordingly, their roles, offices, and social statuses. On the other hand, law's rituals create an as if dimension in which social subjects have the possibility of renegotiating social reality. This is the transformative and innovative function, played by law's discursive dimension, in which social subjects trigger and handle social change' (p. 187).

Ibid., 182. For Rappaport the ritual is also characterized by its formality, invariance and redundancy as a performative activity. Croce refers to Rappaport 1999. At p. 24 of Rappaport's book, the following definition can be found according to which a ritual is: 'the performance of more or less invariant sequences of formal acts and utterances not entirely encoded by the performers'.

Croce 2012, 182.

$9 \quad$ Ibid. Croce refers to Austin 1962. 
port of 2019, whereby the addition of 'belief' to 'religion' is meant to convey the protection of 'non-believers'. Such apparent nonsense - non-believers should rely on the term 'belief' for protection - does indeed make sense, but only if one adopts the ritual code of the 'performers', i.e. of the authors of the Report and their public, possibly beyond their control on the entire encoding of the formula. Key to the definition is the understanding of the expression 'freedom to have' in international documents as implying the 'freedom not to have', as well as of 'belief' as inclusive of non-belief, or non-religious belief. Such understanding does not need to be explicit, or even conscious in order for the formula to impact on reality.

Besides fulfilling the ritual requisite as a formulaic articulation, thus discouraging specification, if the formula 'freedom of religion or belief' as such has not been made the object so far of further analysis, I posit, it is because of two factors.

First, experts and actors have rather focused on making the formula effective in key sectors and legal frames, such as labour law and family law, or anti-discrimination law and criminal law. In this context, the definition of 'religion' was at stake in the face of discrimination claims from groups labelled as cults or sects (e.g., whenever the Church of Scientology was denied protection, and even attacked, because it was not deemed entitled to protection qua 'religion'), or as extremist groups (e.g., whenever Jehovah's Witnesses were restricted because of their alleged extremist views and actions). In turn, the definition of 'belief' was central in the face of recognition of equality claims from non-religious or anti-religious groups. This drove experts away from questioning the very formula 'freedom of religion or belief', and towards working on specific aspects of its formulation, such as the words 'religion' and 'belief' for the sake of its sectorial application.

As for the second factor, against the background of more than seventy years of scholarly literature and international documents, those who care for human rights in general and 'religion or belief' rights in particular, often feel that the true priority today is the implementation of standards of protection, rather than their textual refinement. Persecuted believers or non-believers matter more than the phrasing of commitments in international documents. The priority of implementation is the principle that Ahmed Shaheed put at the top of the agenda upon his appointment in 2016 as the UN Special Rapporteur on Freedom of Religion or Belief, as he pur- 
ported to denounce and fill 'the gap between commitments to combat intolerant acts and practices and their implementation'. ${ }^{10}$

According to my two-factor hypothesis, the FoRB formula is thus overlooked as a distinct, performative, linguistic agent and as a powerful indicator of and factor for developments in the area. This would be due to the fact that the formula is usually understood as a short hand term and acronym (like UDHR for the Universal Declaration on Human Rights), not to be paid special attention as such, and that experts are busy with improving its application in critical domains on the one hand, and with making it work in the implementation phase on the other.

Far from distracting from the implementation of the formula, and far from undermining the consensus built on its broadness, this article argues that more and better knowledge about the past and present of the formula 'freedom of religion or belief' is likely to result in a stronger consistency between the terminology and the concept, while being conducive to a richer national and international conversation on the protection and promotion of 'religion or belief' related rights and freedoms. I will articulate my argument in four steps, each corresponding to one section. In the first section (The emergence), I will succinctly map the chronology and context of the emergence of the formula: while confirming the importance of the United Nations, I will emphasize that UN documents were not alone, and were not in isolation. In particular, I will underline the importance of the Conference, then Organisation for Security and Cooperation in Europe, and of a general international conversation, accelerated by the adoption in 1998 of the US International Religious Freedom Act. In this regard, although focusing on international documents and not providing a systematic review of the relevant literature, I will nonetheless underline the decisive role of scholarship in the process. In the second section (The features), I will formulate a hypothesis about the most significant features of the formula, and suggest that those features should be identified as the reasons why in the last two decades the formula has proved relatively successful at

10 UN General Assembly, Interim report of the Special Rapporteur on freedom of religion or belief, Ahmed Shaheed, 28 August 2017, n. 74 (https://undocs.org/A/72/365; last visited 1 July 2020). Ahmed Shaheed made his implementation agenda even clearer in the interview he gave in Athens in July 2018. See Ventura 2018. 
the UN and OSCE level, as well as in the context of the European Union, mainly in its external action. In the third section (The EU laboratory), I will map the formula in the EU context and offer an interpretation of the EU framework as a laboratory where the formula is received, challenged and reinvented in a variety of ways. I will argue that the process is crucial for actors engaged in dynamically navigating the tension between universality and diversity, the action outside the EU and inside the EU, the English encoding of the formula and its resonance in the languages and cultures of EU Member States. In the fourth and final session (The translation), I will offer ten sets of questions related to the linguistic and legal translation of the formula in EU Member States. If addressed, I hold, those questions might considerably improve knowledge on the formula in both its topdown and bottom-up dynamic unfolding, thus empowering scholars and actors engaged with combining the global ritual power of the formula in English and its variations in different languages and cultures.

\section{THE EMERGENCE}

The above-quoted opening sentence of the 2013 EU Guidelines on the promotion and protection of 'freedom of religion or belief' borrows its key words - thought, conscience, religion and belief - from article 18 of the Universal Declaration of Human Rights of 1948 (UDHR) and from article 18 of the International Covenant on Civil and Political Rights of 1966 (ICCPR). ${ }^{11}$ In fact, since the 2013 EU Guidelines are meant to

11 According to article 18 UDHR, 'Everyone has the right to freedom of thought, conscience and religion; this right includes freedom to change his religion or belief, and freedom, either alone or in community with others and in public or private, to manifest his religion or belief in teaching, practice, worship and observance' (https://www.un.org/en/ universal-declaration-human-rights/; last visited 1 July 2020). Article 18 ICCPR stipulates that ' 1 . Everyone shall have the right to freedom of thought, conscience and religion. This right shall include freedom to have or to adopt a religion or belief of his choice, and freedom, either individually or in community with others and in public or private, to manifest his religion or belief in worship, observance, practice and teaching. 2. No one shall be subject to coercion which would impair his freedom to have or to adopt a religion or belief of his choice. 3. Freedom to manifest one's religion or beliefs may be subject only to such limita- 
frame the external action of the EU, they need to be based on a standard of global applicability, and therefore they can only rely on international sources applicable worldwide. This is the case of 'articles 18'. From the perspective of the European Union, they prove foundational of the formula, more than European sources themselves, because they are applicable worldwide, and because they are fully consistent with European human rights.

In fact, as it comes to legal sources of European law, the same four key words can also be located in article 9 of the European Convention on Human Rights of 1950 (ECHR), the Convention having been signed by Member states of the European Communities, then the European Union. ${ }^{12}$ Since the adoption of the EU Charter of Fundamental Rights in 2000, the four words can also be found in article 10 of the Charter, the first paragraph of which has the same text as the first paragraph of article 9 ECHR. ${ }^{13}$

tions as are prescribed by law and are necessary to protect public safety, order, health, or morals or the fundamental rights and freedoms of others. 4. The States Parties to the present Covenant undertake to have respect for the liberty of parents and, when applicable, legal guardians to ensure the religious and moral education of their children in conformity with their own convictions' (https://www.ohchr.org/en/professionalinterest/pages/ccpr.aspx; last visited 1 July 2020).

12 Article 9 ECHR: '1. Everyone has the right to freedom of thought, conscience and religion; this right includes freedom to change his religion or belief and freedom, either alone or in community with others and in public or private, to manifest his religion or belief, in worship, teaching, practice and observance. 2. Freedom to manifest one's religion or beliefs shall be subject only to such limitations as are prescribed by law and are necessary in a democratic society in the interests of public safety, for the protection of public order, health or morals, or for the protection of the rights and freedoms of others' (https://www.echr.coe. int/Documents/Convention_ENG.pdf; last visited 1 July 2020).

13 Article 10 of the EU Charter of Fundamental Rights: '1. Everyone has the right to freedom of thought, conscience and religion. This right includes freedom to change religion or belief and freedom, either alone or in community with others and in public or in private, to manifest religion or belief, in worship, teaching, practice and observance. 2 . The right to conscientious objection is recognised, in accordance with the national laws governing the exercise of this right' (https://eur-lex.europa.eu/legal-content/EN/TXT/?uri=CELEX:12012P/TXT; last visited 1 July 2020). The correspondence between article 10 of the EU Charter of Fundamental Rights and article 9 ECHR is acknowledged in the Explanations of the Praesidium of the Convention in charge of drafting the Charter, as later amended and published in 2007. As for article 10, Explanations clarify that 'the right guaranteed in paragraph 1 corresponds to the right guaranteed in Article 9 of the ECHR and, in accordance with 
The authentic version of the European Convention on Human Rights is bilingual English and French. ${ }^{14}$ The equivalent in French for the four English words is 'pensée' (for thought), 'conscience' (for conscience), 'religion' (for religion) and 'conviction' (for belief).

With the EU Charter of 2000, officially published in the languages of EU Member States, the four key words of article 10 have official equivalents in the languages of EU Member States. For example, the equivalent of thought, conscience, religion and belief is, respectively, in Polish, 'myśl', 'sumienie', 'religia' and 'przekonania', in German 'Gedanke', 'Gewissen', 'Religion' and 'Weltanschauung', in Spanish 'pensamiento', 'conciencia', 'religión' and 'convicciones', and in Italian 'pensiero', 'coscienza', 'religione' and 'convinzione'. ${ }^{15}$ The same applies to the expression 'religion or belief' used by article 10 when singling out freedom to change one's own 'religion or belief' as well as freedom to manifest one's own 'religion or belief'. For example, in Polish it is 'religia lub przekonania', in German it is 'Religion oder Weltanschauung', in Spanish it is 'religión o convicciones', and in Italian it is 'religione o convinzione'. ${ }^{16}$

The adoption of the 2013 EU Guidelines did not provide the same official translation in each language of EU Member States for the formula 'freedom of religion or belief', since the Guidelines were not officially published in the languages of EU Member States. However, the European Parliament voted a Recommendation to the Council of 13 June 2013 on the draft EU Guidelines on the Promotion and Protection of Freedom of Religion or Belief. ${ }^{17}$ This document does indeed provide an official translation of

Article 52(3) of the Charter, has the same meaning and scope'. 'Explanations relating to the Charter of Fundamental Rights' (2007/C 303/02) (https://eur-lex.europa.eu/legal-content/EN/TXT/?uri=CELEX\%3A32007X1214\%2801\%29; last visited 1 July 2020).

14 As explained in the website of the European Court of Human Rights, 'only the English and French versions are authentic'. In addition, the website offers 'translations into non-official languages' coming 'from various sources' (https://www.echr.coe.int/Pages/ home.aspx? $\mathrm{p}=$ basictexts/convention; last visited 1 July 2020).

15 For different language versions of the Charter, see https://eur-lex.europa.eu/legal-content/EN/TXT/?uri=CELEX:12012P/TXT (last visited 1 July 2020).

16 Ibid.

17 The Recommendation is available at https:/eur-lex.europa.eu/legal-content/EN/ TXT/?qid=1588436757893\&uri=CELEX:52013IP0279 (last visited 1 July 2020). 
the formula, possibly the first one chronologically in an EU document. Accordingly, for example, the formula is translated as 'wolność religii lub przekonań' in Polish, 'Religions- und Weltanschauungsfreiheit' in German, 'libertad de religión o creencias' in Spanish, 'libertà di religione o di credo' in Italian, 'liberdade de religião ou de crença' in Portuguese, 'vrijheid van godsdienst en overtuiging' in Dutch, 'religions- og trosfrihed' in Danish, 'elefthería thriskeftikís syneídisis í pepoithíseon' in Greek and 'vallás vagy meggyőződés szabadságának' in Hungarian.

Although the text of the 2013 EU Guidelines and the text of the Helsinki Declaration put the four key words all together and at the same level, the actual formulation of the four foundational articles - article 18 UDHR, article 18 ICCPR, article 9 ECHR and article 10 of the EU Charter of Fundamental Rights - differentiate between the reference to the right to 'freedom of thought, conscience and religion', and the reference to the freedom to change one's own 'religion or belief' as well as to the freedom to manifest one's own 'religion or belief'. In the four articles, 'freedom of thought, conscience and religion' 'includes' both freedom to change one's own 'religion or belief' as well as to freedom to manifest one's own 'religion or belief'. ${ }^{18}$ Article 18 ICCPR has the expression 'freedom to have or to adopt a religion or belief of his choice', and not the expression 'freedom to change'.

The 2013 EU Guidelines give no reference for the expression 'freedom of thought, conscience, religion or belief' used in the opening sentence. Indeed, that very expression is used in the Helsinki Declaration (The Helsinki Final Act) of 1975, principle VII, paragraph 1, possibly for the first time in an official international human rights document. ${ }^{19} \mathrm{~A}$ few years later,

18 The expression 'freedom of thought, conscience and religion' is present in the four articles and provides the official title of both article 9 ECHR and article 10 of the EU Charter of Fundamental Rights. The right to 'freedom to change his religion or belief' can be found at article 18 UDHR and at article 9 ECHR. Article 10 of the EU Charter of Fundamental Rights has rather 'freedom to change religion or belief'. The right to 'freedom to manifest his religion or belief' can be found at article 18 UDHR, article 18 ICCPR, and article 9 ECHR. Article 10 of the EU Charter of Fundamental Rights has rather 'freedom to manifest religion or belief'. Article 18 ICCPR, and article 9 ECHR also mention 'freedom to manifest one's religion or beliefs', with the plural 'beliefs'.

19 For the text of the Helsinki Declaration, see https://www.csce.gov/sites/helsinkicommission.house.gov/files/Helsinki\%20Final\%20Act.pdf (last visited 1 July 2020). 
the same expression 'freedom of thought, conscience, religion or belief' is also used in the Preamble of the 1981 UN Declaration on the Elimination of all Forms of Intolerance and of Discrimination based on Religion or Belief. ${ }^{20}$

If it is relatively easy to identify the antecedents and sources for the formula 'freedom of religion or belief' in the above-mentioned four articles, two pertaining to international law of global applicability and two pertaining to the system of protection of fundamental rights in the European space as defined by the signatories to the European Convention on Human Rights and by EU Member States, ${ }^{21}$ it is more problematic to identify the chronology and context of the emergence of the formula. As illustrated in the following pages and in the two timeline tables published at the end of this article, ${ }^{22}$ my hypothesis is that the formula has emerged in the context of the United Nations, as a result of the interpretation of article 18 UDHR and article 18 ICCPR in the light of the 1981 Declaration on the Elimination of All Forms of Intolerance and of Discrimination based on Religion or Belief. In fact, it is in the Preamble to the 1981 Declaration that the formula can be found, possibly for the first time in an official international human rights document. The parties consider that 'religion or belief, for anyone who professes either, is one of the fundamental elements in his conception of life and that freedom of religion or belief should be fully respected and guaranteed'. The formula is reiterated at article 5 (3), whereby a child 'shall be brought up in a spirit of (...) respect for freedom of religion or belief of others'.

Following the example of the UN, and as a result of the interpretation of the Helsinki Declaration of 1975, the formula has also emerged

20 The UN Declaration is available at https://www.ohchr.org/EN/ProfessionalInterest/ Pages/ReligionOrBelief.aspx (last visited 1 July 2020).

${ }^{21}$ If principle VII, paragraph 1 of the Helsinki Declaration is also taken into account, the space corresponding to the territory of the Participating States to the Organisation for Security and Cooperation in Europe should also be considered.

${ }^{22}$ The first table offers a timeline of significant steps in the international emergence of the formula from a European perspective. The second table offers a timeline of significant steps in EU law. My main reference for this exercise is the Dictionnaire du droit des religions edited by Francis Messner in 2010. The Dictionnaire has a chronological list of legal documents (Liste chronologique des textes juridiques cités) at pp. 721-757 and a list of court cases (Liste chronologique des decisions de juridpudence citéés) at pp. 759-784. 
in the Helsinki process. ${ }^{23}$ It can be traced in the 1999 OSCE/ODIHR background paper by Cole Durham. ${ }^{24}$ The document refers to the OSCE/ ODIHR Advisory Panel of Experts on Freedom of Religion, of which Cole Durham was himself a member at the time. The same Panel is referred to as the Advisory Panel of Experts on Freedom of Religion or Belief in the Panel's 2004 OSCE/ODIHR 'Guidelines for Review of Legislation Pertaining to Religion or Belief'. This indicates that the Panel was renamed between 1999 and 2004, ${ }^{25}$ or, as Jeremy Gunn seems to suggest, that since its creation in 1996 the Panel was indeed named 'Advisory Panel of Experts on Freedom of Religion or Belief', ${ }^{26}$

If the transition to systematic use of the formula 'freedom of religion or belief' can be located in the late nineties within the OSCE framework, that period of time is also key for the adoption of the formula at the United Nations level. ${ }^{27}$ After the reference to 'freedom of religion or belief' in the 1981 Declaration on discrimination, the formula had not been systematically adopted. In the 1992 'Declaration on the Rights of Persons Belonging to National or Ethnic, Religious and Linguistic Minorities', only the term 'religious' is employed, coupled with 'minorities', 'identity', 'life', and 'ties'. ${ }^{28}$ In 1993, the General Comment on article 18 by the Human Rights Committee does not include the expression 'freedom of religion or belief', but rather 'freedom of religion and belief' and 'freedom of thought,

23 My understanding of the Helsinki process and its impact on religion is based on my research association with Giovanni Barberini, and builds on his foundational works. See, in particular, Barberini 2004.

24 See Cole Durham 1999.

25 If this was the case, I have not been able to establish when exactly this occurred, and whether this came as an official step, or not.

26 See Gunn 2004, 722.

27 In my history of religion in Indian, South African and British courts, I have categorised those years as a transition period from the nationalisation of religion (period 1995-2000, for which I use the metaphor of 'national gods') to the globalisation of religion (first decade of the 2000s, for which I use the metaphor of 'global gods'). See Ventura 2014a.

28 UN General Assembly, Declaration on the Rights of Persons Belonging to National or Ethnic, Religious and Linguistic Minorities, 18 December 1992, Resolution 47/135 (https://www.ohchr.org/EN/ProfessionalInterest/Pages/Minorities.aspx; last visited 1 July 2020). On the emergence of the category of religious minorities, see the overview in Ferrari 2019 (in particular at pp. 166-178). 
conscience, religion and belief'. ${ }^{29}$ Yet, in 2000 the Commission on $\mathrm{Hu}-$ man Rights decides to change the mandate title of the previously 'Special Rapporteur on Religious Intolerance' to 'Special Rapporteur on Freedom of Religion or Belief'. ${ }^{30}$

As anticipated, it is thus possible to formulate the hypothesis that after the human rights documents of 1948 (UDHR), 1950 (ECHR) and 1966 (ICCPR) set the textual basis for it, the formula begun to emerge in the seventies with the reference to 'religion and belief' in the Helsinki Declaration, surfaced in 1981 in the UN Declaration on discrimination, and was consolidated in the late 1990s and early 2000s. In the same period of time, scholars have contributed decisively to both the formula and the acronym FoRB. Bahia Tahzib published her foundational work in 1996 and was key to the later Deskbook she edited along with Cole Durham and Tore Lindholm. ${ }^{31}$ According to Cole Durham, Bahia Tahzib should be credited with the consolidation of the formula as a working tool, and with the forging of the acronym as well. This means that the Dutch experts advising Tahzib in her doctoral thesis, and the Foreign Ministry of The Netherlands where she worked probably had a decisive influence. ${ }^{32}$ As confirmed by Lena Larsen of the Norwegian Centre for Human Rights, the involvement of the Oslo Coalition on Freedom of Religion or Belief, along with Brigham Young University during the preparation of the Deskbook illus-

29 UN Human Rights Committee, CCPR General Comment No. 22: Article 18 (Freedom of Thought, Conscience or Religion), 30 July 1993, CCPR/C/21/Rev.1/Add.4 (https:// www.refworld.org/docid/453883fb22.html; last visited 1 July 2020). See the analysis in Angeletti 2008, 41-43.

30 In our email exchange of May-June 2020, Jeremy Gunn recalled from memory that Special Rapporteur Abdelfattah Amor (who served from April 1993 to July 2004) wanted his title to be changed to 'Special Rapporteur for Freedom of Religion or Belief' to reflect the emerging international formulation and show that he was doing more than combatting intolerance. My thanks to Jeremy Gunn for sharing the information.

31 See Tahzib 1996. The Deskbook is Facilitating Freedom of Religion or Belief. A Deskbook, edited by W. Cole Durham, Tore S. Lindholm, and Bahia G. Tahzib-Lie (Leiden: Brill, 2004).

32 My thanks to Cole Durham for this piece of information shared in an email exchange in May 2020. He names Theo van Boven and Harm Hazewinkel as the Dutch experts who might have had a special influence. 
trates that the rise of the formula was a joint, more or less deliberate, effort of scholars and actors. ${ }^{33}$

As witnessed by the cooperation of European and American scholars in the preparation of the Deskbook, the formula emerged after the mid-1990s as a result of simultaneous, interconnected developments on both sides of the Atlantic. ${ }^{34}$ A key step was the adoption in the United States of the 1998 International Religious Freedom Act. ${ }^{35}$ It seems plausible that the forging of the formula 'international religious freedom (IRFA)' in the US and the contemporary emergence of the formula 'freedom of religion or belief' in the UN and the OSCE witness both the converging reaction to the growing concern for the pressure on 'religion or belief' related rights and freedoms worldwide, ${ }^{36}$ and the diverging strategies with respect to terminological preferences and formulaic articulations. ${ }^{37}$

At the end of this section, and before delving into a presentation of features of 'freedom of religion or belief', I need to briefly discuss the largely

33 My thanks to Lena Larsen for confirming the role of the Norwegian experts and institutions in our email exchange. According to her recollection, during an editorial meeting on Facilitating Freedom of Religion or Belief. A Deskbook, one of the editors expressed the opinion that 'freedom of religion or belief' was too long to pronounce every time the topic was mentioned, and suggested that FoRB would be used instead.

34 See the two volumes edited by Johan D. van der Vyver and John Witte Jr. (Religious Human Rights in Global Perspective, The Hague: Martinus Nijhoff, 1996). The importance of the international conference resulting in this publication is emphasized in Gunn 2004, 722. See also Boyle, and Sheen (eds.) 1997. It is worth noticing the analogous use of the formula in Tahzib's book of 1996 and in the 1997 book edited by Boyle and Sheen.

35 In his chapter for the 2004 Deskbook, Jeremy Gunn presents the background and implications of the adoption of the Act. See Gunn 2004, 717-742.

36 In 2015 Pasquale Annicchino has illustrated the US initiative, and its value as a template worldwide, especially for European states. As expressed in the title of his book, Annicchino sees this phase as characterised by an agenda, and ideal of 'exporting religious freedom'. See Annicchino 2015. The book was later translated into English with a title no longer explicitly referring to 'exporting religious freedom'. See Annicchino 2017. A reference to 'exporting freedom' is in the title of Anna Su's presentation and discussion of the US foreign policy on religion. See Su 2016.

37 Significantly, in their 2010 Law and Religion: National, International, and Comparative Perspectives (New York: Aspen Publishers, 2010), Cole Durham and Brett Sharffs introduce the concept of 'freedom of religion or belief' in the framework of 'international human rights' (from p. 77 on). 
overlooked fact that no matter how close to freedom to 'change', 'have or adopt' and 'manifest' one's own 'religion or belief', the formula 'freedom of religion or belief' cannot be said to be already in the text, as it happens with 'freedom of thought, conscience and religion' and 'freedom of thought, conscience, religion and belief'. The fact that the formula as such is not in the documents is rarely acknowledged. As in the above-mentioned Danish Report of 2019, what matters for experts and actors is that the right and freedom the formula is meant to protect are indeed formulated in international human rights sources. ${ }^{38}$ This confirms the dominant approach to the formula as a short hand expression (and term, in the FoRB version), summarising all aspects that are already in the texts of the four articles, or that can be extracted through incremental interpretation. In this sense the formula would be synonymous of 'freedom of thought, conscience and religion', with as broad a scope of protection as possible. If this is unequivocally held by protagonists of the emergence of the formula, as Jeremy Gunn himself, ${ }^{39}$ and by latest proponents, as the authors of the 2019 Danish Report, I still find that the gap between the dominant interpretation, and the normative text, however minor, should be acknowledged as a space for alternative readings, intentionally or unintentionally departing from the dominant one. It is the case, hypothetically, of attempts aimed at identifying a more precise, limited, and possibly stronger area of protection. In this sense, someone sceptical about the equivalence between religion and belief might interpret the formula as prioritising the term 'religion', which is the only word to be present in both the normative textual expressions 'freedom of thought, conscience and religion', and 'religion or belief'. The formula could also be understood as prioritising the term 'belief' over the terms 'thought' and 'conscience'. It is also possible to read the preference for the formula as indicating the emergence of a predominant concern for the 'manifestation' of thought, conscience, religion and belief. In this sense, the formula would be nothing but the abbreviation

38 In this regard, the Danish Report of 2019 states that 'the international human right to freedom of religion or belief as we know it today was first formulated in the Universal Declaration on Human Rights (1948)'. See Petersen, and Marshall 2019, 11.

39 I refer here to our email exchange of May-June 2020. My thanks to Jeremy Gunn for his comments on this point. 
of the expression 'freedom to manifest his religion or belief' as used in the above-mentioned four articles. The same could be said with regard to a predominant concern for the right to have or not to have a religion or belief: in this case the formula could be understood as the abbreviation of the 'freedom to have or to adopt a religion or belief of his choice' of article 18 ICCPR. ${ }^{40}$ Of course, it is also possible that when the formula is understood as the abbreviation of the 'freedom to have or to adopt a religion or belief of his choice' of article 18 ICCPR, the intention is to take this freedom as including all freedoms protected by article 18, although this would go against article 18 itself, which formulates the freedom of thought, conscience and religion as 'including' the 'freedom to have or to adopt a religion or belief of his choice', and not as its 'equivalent'. Again, I am presenting these hypothetical readings not as a challenge to the dominant understanding of the formula, but as an invitation to reflect on the potential for desirable or undesirable variations, and even for formally diverging definitions, based on the fact that the formula as such is not in the documents, but has been forged as a practical expression capturing the broad scope of protection warranted in the documents.

\section{THE FEATURES}

So far my FoRB mapping hypothesis has been concerned with the textual development of the formula by reference to the chronology and the context. Now I am going to formulate a second, complementary FoRB mapping hypothesis which is concerned with the substantive features of the formula, and the corresponding possible reasons for its success. According to this second hypothesis, six features of the formula have been decisive for its emergence, and impact: 1) it is inclusive of religion and belief and does not isolate any of them; 2) it is inclusive of both the disjunctive and the conjunctive 'or'; 3) it is inclusive of religious diversity; 4) it is inclusive of belief diversity; 5) it is inclusive of a diverse articulation of religion, belief, the State, supranational institutions and organisations, and

40 See Annual Report 2017 (FoRB\&RT European Parliament Intergroup, 2017), p. 6. 
legal systems; 6) it is freedom-oriented and rights-oriented in a threefold individual, collective and institutional meaning.

The first feature concerns the fact that contrary to the previous expressions such as 'religious freedom', 'freedom of religion' or 'religious liberty', where religion poses as a stand-alone word and reference, the formula 'freedom of religion or belief' is eminently inclusive, and does not understand religion or belief, in isolation. The point was made already in 1960 when the UN Special Rapporteur of the Sub-Commission on the Prevention of Discrimination and Protection of Minorities Arcot Krishnaswami adopted the expression 'religion or belief', which he took as one single term, as including 'in addition to various theistic creeds, such other beliefs as agnosticism, free thought, atheism and rationalism' ${ }^{41}$ The approach has been repeatedly confirmed since. As the 2004 OSCE/ODIHR 'Guidelines for Review of Legislation' put it, 'international standards do not speak of religion in an isolated sense, but of "«religion or belief»' ${ }^{42}$ Terminological variations may include a reference to 'religious or non-religious belief', as in the 2019 OSCE/ODIHR document on 'Freedom of Religion or Belief and Security. Policy Guidance', which mentions 'religious or non-religious belief systems' ${ }^{43}$

Until the collapse of Communism in Europe, the dualistic 'religion or belief' structure of the formula was certainly rooted in, and accounting for the bilateral world of the Cold War, ${ }^{44}$ with adherence to Marxist-Leninist, State atheism being categorised alternatively as 'non-belief', by opposition to pre-modern superstitious and irrational beliefs, and as "non-reli-

41 Krishnaswami 1960, 1 (in the footnote). The author indicated that the expression 'religion or belief' was adopted 'in view of the difficulty of defining «religion»'.

42 In our email exchange of May-June 2020, Jeremy Gunn underlined the close connection between the preparation of this document, of which he was the main author, and the Oslo Deskbook (see the reference above). Both the OSCE/ODIHR Guidelines for Review of Legislation Pertaining to Religion or Belief and the Deskbook were published in 2004. My thanks to Jeremy Gunn for this information.

43 See p. 41 (https://www.osce.org/files/f/documents/e/2/429389.pdf; last visited 1 July 2020).

44 See the work by Linde Lindqvist about the context and factors impacting on the formulation of article 18 UDHR: Lindqvist 2017. For the travaux préparatoires of article 18 ICCPR, see Angeletti 2008, 38-40 (with a summary of works by Marc Bossuyt, Malcolm Evans, Manfred Novak and Paul Taylor). 
gious belief', by reference to the opposition between the 'good' rational faith in the ideals and promise of Communism and the 'bad', old religious faith. After the demolition of the Berlin Wall, the alternative between belief and non-belief, and between religious and non-religious belief turned into something more nuanced and complex, this further encouraging precursors of the formula to adopt 'freedom of religion or belief' as coinciding with 'freedom of thought, conscience and religion', and warranting for the broadest scope of rights protection. While being still reminiscent of the iron curtain splitting Europe in two, the formula made space for new trajectories of belief and for the resulting porous boundaries between belief and non-belief, religious and otherwise. ${ }^{45}$ Witnessing the transition from a capitalism/Communism-based to a nuanced and blurred dualism of belief and non-belief, in 1993 the European Court of Human Rights gave an articulated understanding of the bi-dimensional right protected by article 9 ECHR. In its seminal decision on the Kokkinakis case, the Court said that 'freedom of thought, conscience and religion (...) is, in its religious dimension, one of the most vital elements that go to make up the identity of believers and their conception of life, but it is also a precious asset for atheists, agnostics, sceptics and the unconcerned' ${ }^{46}$ In that same period, the resilience of the old capitalism/Communism-based dualism and the emergence of the new broader dualism were significantly experienced in post-communist European countries. It was the case with the Constitution of Poland of 1997, the preamble of which acknowledged 'both those who believe in God as the source of truth, justice, good and beauty, as well as those not sharing such faith but respecting those universal values as arising from other sources'. ${ }^{47}$

In the last twenty years, the dualism of the formula has been consolidated, and further broadened, so as to include not only individuals, but

45 For a more detailed presentation of the transition illustrated in these lines, see Ventura 2019a, 134-145. More generally on the meaning of the term 'secular' and the concept of secularity in Europe: Ventura 2010, 947-961.

46 European Court of Human Rights, Kokkinakis v. Greece, application 14307/88, decided 25 May 1993, at para. n. 31.

47 Constitution of Poland, 1997. English translation available on the website www.sejm. gov.pl (last visited 1 July 2020). In general, on the transition to freedom-based law and religion in post-communist European countries, see Ferrari, Durham, and Sewell (eds.) 2003. 
organisations as well. As a result of a process lasting from the Treaty of Amsterdam of 1997 to the Treaty of Lisbon of 2007, the European Union provided the most powerful statement in this sense through article 17 of the Treaty on the Functioning of the European Union (TFEU). ${ }^{48}$ Although the formula 'freedom of religion or belief' is absent, the article protects on the one hand, under paragraph 1, 'churches and religious associations or communities in the Member States' and on the other hand, under paragraph 2, 'philosophical and non-confessional organisations'. Paragraph 3 of the same article addresses both categories and provides that 'recognising their identity and their specific contribution, the Union shall maintain an open, transparent and regular dialogue with these churches and organisations'. We are faced here with the second feature of the formula, and with the second reason for its success. The formula can work in both directions: by dividing actors who understand themselves as fundamentally different, and by uniting them. The 'or' in the formula 'freedom of religion or belief' can thus be both conjunctive and disjunctive: it can be hospitable to competition, and even conflict, and at the same time it can make space for dialogue, and even strategic partnerships, in an increasingly coalition-based approach to FoRB. ${ }^{49}$ Along the same line, the formula can convey concepts of distinction between religion and belief, while being open to opposite concepts of impossible distinction between the two in a continuum of religion and non-religion. As in article 17 TFEU, it can trigger separate norms, one for each category, and it can also pull the two categories together in one single norm, as paragraph 3 of the article does. ${ }^{50}$

48 Article 17 of the Treaty on the Functioning of the European Union: ' 1 . The Union respects and does not prejudice the status under national law of churches and religious associations or communities in the Member States. 2. The Union equally respects the status under national law of philosophical and non-confessional organisations. 3. Recognising their identity and their specific contribution, the Union shall maintain an open, transparent and regular dialogue with these churches and organisations' (https://eur-lex.europa.eu/legal-content/EN/ $\mathrm{TXT} /$ ?uri=celex\%3A12012E\%2FTXT; last visited 1 July 2020).

49 The importance of 'broader alliances and coalitions', possibly including 'non-religious actors', is emphasised in 'International Promotion of Freedom of Religion or Belief. Sketching the Contours of a Common Framework', cit., p. 67 and p. 72.

50 It is still debated whether under this article the EU Commission is required to carry joint or separate consultations of religious and non-religious actors. 
While functioning in different, possibly opposite ways on the two sides of its binary formulation, the formula has the advantage of allowing for a broad understanding and inclusion of who is entitled to protection within each of the two sides, and in between. This is what features three and four are about, as exemplarily expressed in the UN General Comment on article 18 UDHR of 1993, the same year of the Kokkinakis decision. Indeed, according to the Comment, article 18 'protects theistic, non-theistic and atheistic beliefs, as well as the right not to profess any religion or belief' and therefore 'the terms «belief» and «religion» are to be broadly construed' ${ }^{51}$

As for the third feature, FoRB has the quality, and the advantage of broadening up the field of religion, thus responding to increasing fundamental criticism of the very possibility of the category 'religion'. ${ }^{52}$ As clarified in the same UN General Comment of 1993, article 18 'is not limited in its application to traditional religions or to religions and beliefs with institutional characteristics or practices analogous to those of traditional religions', nor is it to be understood as excluding 'newly established' or minority religions or beliefs. If broadly construed, the formula is resilient to shifting definitions of religion in society, and specifically in the law. ${ }^{53}$

51 UN Human Rights Committee, CCPR General Comment No. 22, n. 2.

52 In our introductory text on new approaches in the study of religion, Claudio Ferlan and I have pointed at the tension between the contemporary contestation of the category of religion amongst scholars, and the resilience of the category amongst actors. See Ferlan, and Ventura 2018, 15-18. For a major critique of the category as uniquely Western, and Christian, see Dubuisson 2020. The scholarly impossibility of the category of religion has impacted on the debate on religious freedom and freedom of religion or belief, as spectacularly illustrated by the controversial thesis of Winnifred Sullivan on the impossibility of religious freedom. See Sullivan 2018. Contra, Marc DeGirolami argued that a legal notion of religion is indeed possible, and that religious freedom is by consequence also possible, if understood in its necessarily tragic dimension. See DeGirolami 2013.

53 In his opinion for the UK Supreme Court in the 2013 decision favourable to the registration of marriages in the Church of Scientology, Justice Toulson exemplifies the hardship of legally defining religion, as well as the broad definition often adopted in European laws: 'I would describe religion in summary as a spiritual or non-secular belief system, held by a group of adherents, which claims to explain mankind's place in the universe and relationship with the infinite, and to teach its adherents how they are to live their lives in conformity with the spiritual understanding associated with the belief system. By spiritual or non-secular I mean a belief system which goes beyond that which can be perceived by the senses or ascertained by the application of science. I prefer not to use the word 'supernatural' to 
According to the fourth feature, the same process of broadening up applies to the field of belief, at a time when traditional categories such as atheism and humanism undergo substantial change, and new categories such as the 'nones', which is the 'unaffiliated', are on the rise and pose fundamental challenges to conventional wisdom about the binary identification of the religious and the non-religious. ${ }^{54}$ At the same time, it is also crucial that the category is not left undefined, for the sake of those who need it for protection, especially in complex cases of equality claims and asylum seekers' rights. The definition of 'belief' in the 2004 OSCE/ODIHR 'Guidelines for Review of Legislation Pertaining to Religion or Belief' offers a perfect example in this regard: 'The «belief» aspect typically pertains to deeply held conscientious beliefs that are fundamental about the human condition and the world. Thus, atheism and agnosticism, for example, are generally held to be entitled to the same protection as religious beliefs. It is very common for legislation not to protect adequately (or to not refer at all to) rights of non-believers. Although not all beliefs are entitled to equal protection, legislation should be reviewed for discrimination against non-believers'. As it comes to determining the scope of protection, since 1982, the European Court of Human Rights has crucially established that the term 'convictions' as mentioned in the 1952 Protocol to the European Convention on Human Rights is 'akin to the term beliefs appearing in article $9(\ldots)$ and denotes views that attain a certain level of cogency, seriousness, cohesion and importance', ${ }^{55}$

express this element, because it is a loaded word which can carry a variety of connotations. Such a belief system may or may not involve belief in a supreme being, but it does involve a belief that there is more to be understood about mankind's nature and relationship to the universe than can be gained from the senses or from science. I emphasise that this is intended to be a description and not a definitive formula'. UK Supreme Court, R (on the application of Hodkin and another) v. Registrar General of Births, Deaths and Marriages, 11 December 2013, n. 57, per Justice Toulson.

54 See Balazka 2020. See also an overview on this emerging category in Ventura 2020.

55 European Court of Human Rights, Campbell and Cosans v. The United Kingdom, applications 7511/76 and 7743/76, decided 25 February 1982, at para. n. 36. Thirty years later, the Court reiterated the same expression, word by word, in European Court of $\mathrm{Hu}-$ man Rights in Eweida and Others v. The United Kingdom, applications 48420/10, 59842/10, $51671 / 10$ and 36516/10, decided 15 January 2013, at para. n. 81. Such interpretation is confirmed by the European Court of Human Rights in Guide on Article 9 of the Convention- 
The fifth feature is that the formula 'freedom of religion or belief' is open to a large range of systems of regulation of religion, state-based and non state-based. While in principle challenging every system insofar as it would not protect and promote FoRB, the formula does not identify with any, and therefore is potentially hospitable to all. Moreover, it overcomes the very opposition between freedom of religion or belief and laïcité-laicidad-laicidade-laicità, ${ }^{56}$ as emerged amongst critics of secularism, ${ }^{57}$ thus resulting in the inclusion of France and other countries with similar constitutional principles. The same applies, of course, to the opposition between freedom of religion or belief and systems of established religion, or State preference for one religion over the others.

The sixth and final feature is that the formula is freedom-oriented and rights-oriented. Again, this is extremely inclusive and appealing for a large audience, especially as the formula is understood in the general framework of human rights as universal and inalienable, indivisible, interdependent and interrelated, according to the language commonly adopted after the 1993 Vienna World Conference on Human Rights. While the formula seemed to be aimed predominantly at the protection of individuals, recent developments rather point in the direction of its application to collective rights, and possibly institutional rights as well. ${ }^{58}$ The reference in the 2007 Lisbon Treaty to the status not only of 'churches and religious associations or communities', but also of 'philosophical and non-confessional organisations' seems to point in this direction regardless of whether

Freedom of thought, conscience and religion, 30 April 2020, p. 9 (https://www.echr.coe.int/ Documents/Guide_Art_9_ENG.pdf; last visited 1 July 2020).

56 I am using the words adopted in constitutional law and law and religion in, respectively, French, Spanish, Portuguese and Italian. By doing so I intend to avoid the inaccuracy of the adoption of the French laïcité as encompassing all references to similarly sounding principles formulated in Latin languages, this often coming with reductionist and simplistic notions of French laïcité itself. I have articulated this caveat and suggested a broad European understanding of laïcité and similarly sounding principles in my monograph on the emerging impact on religion of the law of the European Union. See Ventura 2001.

57 Italian sociologist Luca Diotallevi has argued against the absolutism of laicità and has proposed that religious freedom is seen as an alternative to it. See Diotallevi 2010.

58 Jean-Pierre Schouppe has emphasised the existence of a third 'institutional' dimension of religious freedom as both an implication of a correct understanding of religious freedom itself, and a product of the case law of the European Court of Human Rights. See Schouppe 2015. 
collective rights are represented by a church-like religious organization or not. Highly significant of this aspect, as well as of the potential for expansion of the formula, is the adoption of the expression 'religion or belief communities' in the 2014 OSCE/ODIHR 'Guidelines on the Legal Personality of Religious or Belief Communities' ${ }^{59}$ To my knowledge, this is the first international document systematically applying the formula 'religion or belief' to the structuring of 'communities' and, even more significantly, to their 'legal personality'. ${ }^{60}$

I conclude here the presentation of my hypothesis that the emergence and success of the formula are due to the six features illustrated above. I now move to observe the place and explore the potential of the formula in the laboratory of the European Union.

\section{THE EUROPEAN UNION LABORATORY}

The European Union is a unique laboratory of the interaction between religion or belief communities and organisations, states, international organizations, NGOs and the civil society. ${ }^{61}$ On the one hand, beyond religion or belief, the laboratory of the Union consists in an unprecedented experiment of shared sovereignty for a common project involving the construction of a single market, and political and legal integration in many

59 OSCE/ODIHR, Guidelines on the Legal Personality of Religious or Belief Communities, 2014; at https:/www.osce.org/files/f/documents/9/9/139046.pdf (last visited 1 July 2020).

60 The above mentioned 1999 OSCE/ODIHR background paper on 'Freedom of Religion or Belief: Laws Affecting the Structuring of Religious Communities' was certainly a key precursor, but did not adopt the expression, and concept of 'religious or belief communities' as the 2014 document does.

${ }^{61}$ I have used the expression 'laboratory' for the interaction of law and religion in EU law in my 1999 article 'Diritto e religione in Europa: il laboratorio comunitario' (see Ventura 1999, 577-628). Two years later, the concept of the EU laboratory was central in my monograph La laicità dell'Unione europea (see Ventura 2001). Bérengère Massignon later resorted to the same expression in her remarkable overview on religion in the European construction (see Massignon 2007, 17-21). At p. 10, the author refers to the concept of a European laboratory as presented in a text of 2000 by Mgr Noel Treanor, the then Secretary General of the Roman Catholic Commission of the Bishops' Conferences of the EU. 
different areas, including the protection and promotion of human rights. On the other hand, with regard to religion or belief, the laboratory concerns a new institutional setting, and new public policies and legal instruments impacting on religion and belief, including the protection and promotion of 'freedom of religion or belief'. In this perspective, the European Union can also be seen as a laboratory for the formula 'freedom of religion or belief'. Thus, my hypothesis is that the EU laboratory offers crucial indications about the place and potential of the formula both a) when the formula is used, and even adopted, and b) when the formula is not used, but documents and actions have an indirect impact on its use and meaning. I will now present how the EU laboratory affects the formula directly and indirectly, and which indications can be drawn.

As eminently indicated by the adoption of the formula in the 2013 Guidelines, 'freedom of religion or belief' enters the space of the European Union through the door of the Union's external action. ${ }^{62}$ This is fully consistent with the formula being forged in the international arena, by experts working for the international community. In the adoption of the formula through the external action, the peculiar fluidity and complexity of EU institutions and bodies are mobilised. The Guidelines are adopted by the Council after a vote in the European Parliament. The European External Action Service is primarily in charge of their implementation. The diplomatic network of EU delegations is activated. Consolidating the pattern, after a resolution by the European Parliament in February 2016, the President of the European Commission Jean-Claude Juncker created the function of the 'Special Envoy for the promotion of freedom of religion or belief outside the EU' and appointed Ján Figel' to this role in May 2016. With the addition of 'outside the EU' to the formula, its foreign dimension was made explicit, and accentuated.

Since its creation, the office held by Ján Figel' until October 2019 has been a laboratory within the EU laboratory on religion or belief with respect to its architecture, politics, and contents. ${ }^{63}$

62 For an overview on 'religious freedom in the external relations of the European Union', see Part II of Annicchino 2017, 43-73.

63 On 9 July 2020, the Commission has announced the reappointment of the Special Envoy, thus giving continuity to the office beyond Ján Figel"s tenure. 
As for the architecture, the Special Envoy worked across several European institutions, and in particular the Council, the Commission (in its rich articulation) and the European Parliament, as he operated as a Special Advisor to the Commissioner for International Cooperation and Development, and in coordination with the European External Action Service. In this regard, in his 2019 final report, Ján Figel' described his mandate as 'part of a «corporate EU effort» to reinforce our response in the area of FoRB' ${ }^{64}$ An example of such effort is the 'Global Exchange on Religion in Society' launched in 2019 by the European External Action Service. ${ }^{65}$ The work of the European Union Agency for Fundamental Rights should also be taken into consideration as we considered the EU laboratory under the perspective of its institutional architecture.

As for politics, the Special Envoy has been praised by some as he 'steered clear' of politicization of religious freedom and modeled a 'non-politicized kind of promotion', ${ }^{66}$ but he has also been met with harsh criticism at certain occasions, most significantly by European humanists, ${ }^{67}$ this leading the European Ombudsman to warn against the risk of such a 'highly sensitive post being exploited given the clashes that can emerge between freedom of religion and belief and other fundamental rights and freedoms' ${ }^{68}$

64 Figel' 2019, 3.

65 EU Commission, Action Document for Global Exchange on Religion in Society (https://ec.europa.eu/fpi/sites/fpi/files/annex_22_global_exchange_on_religion_in_society. pdf; last visited 1 July 2020). At page 4, the Document illustrates the 'coherence and complementarity' of the Global Exchange with other EU policy initiatives.

66 Annicchino 2020, 77 (for the first quote) and 76 (for the second).

67 On 13 February 2019 a group of EU MPs signed a public letter to the President of the European Commission Jean-Claude Juncker in order to protest against 'the participation of the EU Special Envoy alongside neo-conservative and fundamentalist organisations and individuals who vocally oppose fundamental rights such as women's sexual rights and LGBTI people's rights'. The letter is posted on the website of the European Humanist Federation at https://humanistfederation.eu/meps-to-j-c-juncker-is-eu-special-envoy-for-forb-able-tocarry-out-his-mandate/ (last visited 1 July 2020).

68 European Ombudsman, Decision in case 1553/2019/NH on the role of the EU's Special Envoy for the promotion of freedom of religion or belief outside of the EU, 30 July 2020, at https://www.ombudsman.europa.eu/en/decision/en/130887 (last visited 1 July 2020). As a result of the case, the European Ombudsman recommended that the Commission 1) gives 'clearer guidance' to future Special Envoys 'about the need to take into account the full range of human rights when making statements and interacting with stakeholders'; 
As for contents, Ján Figel' has offered a remarkably forward-looking articulation of FoRB through the five action-oriented recommendations of his 2019 final report. First, the Special Envoy recommended 'work on FoRB within a human rights framework and through the Sustainable Development Goals agenda, including education, gender and peace'. ${ }^{69}$ Thus, the EU places its understanding and operation of the formula in the context of sustainable development. The second recommendation is 'boost FoRB literacy' by 'supporting capacity within government, public sector and security officials, as well as increasing the capacity of civil society organizations and religious actors to be FoRB champions' ${ }^{70}$ The third recommendation, 'support engagement with religious actors and interreligious dialogue', ${ }^{71}$ advances at the same time the principle of engagement, the salience of religious actors and the value of interreligious dialogue. ${ }^{72}$ The fourth recommendation is the most 'outside the EU' oriented as it invites to 'implement a more strategic and contextualized approach at the country level, notably in selected countries'. ${ }^{73}$ Finally, the Special Envoy recommended stepping up 'coordination among Member States and the EU on FoRB'. ${ }^{74}$

As clearly expressed in the creation of the office of the Special Envoy, and in the way Ján Figel' fulfilled his mandate, culminating in the five recommendations, the EU approach to the formula is one of both endorsement and reinvention. While being an egregious example of the fundamentally international nature of the formula, to the point of qualifying FoRB with the 'outside the EU' clause, the office also exemplifies the potential of the formula for widespread travelling across institutions, actions and levels. If, as anticipated above, this applies in many different ways within the EU institutions, interactions have grown increasingly intense between the EU Commission, Member States and the EU Parliament. The Special Envoy's

2) 'clarify the extent to which future Special Envoys have the mandate to speak on behalf of the Commission'; and 3) makes their 'mandate and work plan publicly available'.

69 Figel' 2019, 8.

70 Ibid., 2.

71 Ibid.

72 See in particular Petito, Berry, and Mancinelli 2018.

73 Figel' 2019, 2.

74 Ibid., 11. 
recommendation No. 5 is explicit on the need for further 'coordination' with Member States, especially as many of them develop a FoRB agenda in their own foreign policies, and end up inevitably involving the EU in a transatlantic conversation with the US and Canada, and in further regional and global expressions of religious diplomacy. On this line, at the occasion of the presentation of the five recommendations in Bruxelles, on 15-16 October 2019, the Special Envoy for Religious Freedom of the Minister of Foreign Affairs of Poland Daria Wołosiuk stated that 'we need alliances and broad outreach to like-minded countries, potential new partners, local civil society and religious communities. In this respect coordination is key as it will bring more sound and durable solutions and will result in more consistent and complementary actions. More joint actions, efforts and initiatives are needed as the problem we face is complex and large-scale' ${ }^{75}$

While the European External Action Service and the European Commission play a major role in the adoption and application of the formula, the European Parliament has a considerable role as well, as shown by the foundation, and activities, of the European Parliament Intergroup on Freedom of Religion or Belief and Religious Tolerance. ${ }^{76}$

So far, I have presented the explicit use and adoption of the formula 'freedom of religion or belief' in the EU laboratory. As anticipated, this is not the only contribution of the EU to the emergence, success and characters of the formula, and I now move to explain in which sense some forms of EU engagement with religion and belief have an indirect impact on the formula. This is the case, in particular, a) with the dialogue mandated by article 17 n. 3, b) with EU anti-discrimination law, and c) with references to 'religion or belief' in the case law of the EU Court of Justice.

As anticipated, the main example of indirect impact on the formula is article 17 of the Treaty on the Functioning of the European Union. ${ }^{77}$ Although not directly on freedom of thought, conscience, religion and belief,

75 My thanks to Daria Wołosiuk for sharing this text from her notes in an email exchange in May 2020.

76 A working group was created in the European Parliament in 2012. The Intergroup was started in December 2014. For the creation of the working group, see Perchoc 2017, 6. For the Intergroup see Annual Report 2017 (FoRB\&RT European Parliament Intergroup, 2017), 5.

77 See Ventura 2014b, 293-304. For an overview of the debate about the scope of application of article 17 paragraphs 1 and 2, endorsing my view that the paragraphs should 
the article is highly relevant for the formula in that a) it is a powerful statement about the binary structure of 'religion or belief', b) it acknowledges the corporate dimension of religion or belief communities through its references to their 'status', and c) it requires the Union to maintain an open, transparent and regular dialogue with religion or belief organisations. Such dialogue is organised within the European Commission and the European Parliament and is itself an expression of freedom of religion or belief, as illustrated in the 2013 'Dialogue Implementation Guidelines' issued by the EU Commission, not to be confused with the 2013 Guidelines on FoRB ${ }^{78}$ These Guidelines specify the religion or belief corporate dimension of article 17 as they introduce and regulate the category of 'interlocutors'. The Guidelines also make room for FoRB-related issues as they accept that all parties in the dialogue are not prevented from 'addressing topical issues at any given time'. Finally the 2013 Dialogue Implementation Guidelines are particularly relevant in a 'religion or belief' perspective since they follow 'a decision of the European Ombudsman on the European Humanist Federation's 2011 complaint against the Commission, when it refused to hold a dialogue on human rights in the light of exemptions for religious organisations in the Employment Equality Directive' ${ }^{79}$

The second frame of reference is EU anti-discrimination law. ${ }^{80}$ Introduced in 1997 with the Treaty of Amsterdam, article 13 of the Treaty establishing the European Community commits the European Union to combat

be interpreted as not excluding an impact of the EU on religion within the EU, see Colombo 2020.

78 European Commission, Guidelines on the implementation of article 17 TFEU by the European Commission, 2013. At https://ec.europa.eu/archives/bepa/pdf/dialogues/ guidelines-implementation-art-17.pdf (last visited 1 July 2020).

79 This summary of the case is from the European Parliamentary Research Service, Article 17 TFEU: The EU institutions' dialogue with churches, religious and philosophical organisations, November 2018. The author of the 'In-depth analysis' is Philippe Perchoc. At https://www.europarl.europa.eu/at-your-service/files/be-heard/religious-and-non-confessional-dialogue/home/en-article17-religious-and-non-confessional-dialogue-2018.pdf (last visited 1 July 2020). This refers to the Decision of the European Ombudsman in his inquiry into complaint 2097/2011/RA against the European Commission about the dialogue with philosophical and non-confessional organisations. On the Ombudsman's decision, see the comment in Annicchino 2013, 326-331.

80 This part is based on Ventura 2019b, 239-255. 
discrimination based on, amongst other grounds, 'religion or belief'. After the Lisbon Treaty of 2007, article 13 was transformed into article 19 of the Treaty on the Functioning of the Union. In 2000, the expression 'religion or belief' as a ground for discrimination was reiterated at article 21 of the Charter on Fundamental Rights, and was systematically employed in the 2000/78/EC Council Directive establishing a general framework for equal treatment in employment and occupation. The reference to 'religion or belief' in EU anti-discrimination law is also mobilised in the development of a 'comprehensive EU protection system for minorities' ${ }^{81}$

Particularly significant is the 2004/83/EC Council Directive on the minimum standard for the qualification and status as refugees. The Directive does not resort to the category 'religion or belief' and at article 2 (c) mentions only 'religion' as a pertinent 'reason' for a person to qualify as a refugee based on his or her 'well founded fear of being persecuted'. However, article 10, section 1 (b) offers a very broad definition of the 'concept of religion', where the term 'belief' is used in a peculiar way: 'the concept of religion shall in particular include the holding of theistic, non-theistic and atheistic beliefs, the participation in, or abstention from, formal worship in private or in public, either alone or in community with others, other religious acts or expressions of view, or forms of personal or communal conduct based on or mandated by any religious belief'. The same texts can be found later in the 2011/95/EU Council Directive replacing the Directive of 2004, at articles 2 (d) and 10, section 1 (b). This is possibly a unique, probably unintended experiment, whereby the term 'religion' is explicitly defined as covering what international and European sources usually refer to by the expression 'religion or belief'. In its 2012 preliminary ruling in a case of Pakistani members of the Ahmadiyya religious community seeking asylum in Germany, the Court of Justice of the European Union interpreted the religion-based 'reason' for persecution as peculiarly defined in the 2004 Directive (the 2011 Directive was not yet in force at the time) in the light of article 9 ECHR and article 10 of

81 See Carrera, Guild, Vosyliute, and P. Bárd 2017. In the introduction, the document exposes 'important obstacles in the practical application of non discrimination on grounds of nationality, ethnicity, race, religion or belief, as well as the lack of effective access to and upholding of «group rights»'. Muslim and Jewish communities are explicitly mentioned. 
the EU Charter of Fundamental Rights. ${ }^{82}$ In terms of vocabulary, the Court gave priority to the wording of the Directive, where 'religion' only and not 'religion or belief' is mentioned, to the effect of systematically adopting the formula 'freedom of religion' instead of 'freedom of religion or belief'. The Court defined 'freedom of religion' as one of the foundations of a democratic society and as a basic human right.

Arguably, the nature of the case, and its focus on the status of the undoubtedly religious Ahmadiyya community, pushed the judges to satisfy themselves with 'freedom of religion'. The broad definition of religion in Directive 2004 was however taken into consideration. Responding to the objection that Pakistani Ahmadiyya are not technically persecuted if only limited in the public manifestation of their faith, the Court argued that 'it is unnecessary to distinguish acts that interfere with the «core areas» («forum internum») of the basic right to freedom of religion, which do not include religious activities in public («forum externum»), from acts which do not affect those purported «core areas»' ${ }^{83}$ Acknowledging the Directive's peculiar definition of religion, the Court made clear that 'such a distinction is incompatible with the broad definition of «religion» given by Article 10 (1) (b) of the Directive, which encompasses all its constituent components, be they public or private, collective or individual' and therefore protects 'the applicant's freedom not only to practice his faith in private circles but also to live that faith publicly'. ${ }^{84}$

The creative approach of the Court of Justice in the Ahmadiyya German case is confirmed in other cases decided by the same Court, where the terminology has changed according to the EU legal basis, the national and international law references and the facts of the case. If 'freedom of religion' is probably the most recurrent expression, ${ }^{85}$ the Court has also

82 Court of Justice of the European Union, Bundesrepublik Deutschland, Y, Z v. Vertreter des Bundesinteresses beim Bundesverwaltungsgericht, Bundesbeauftragter für Asylangelegenheiten beim Bundesamt für Migration und Flüchtlinge (preliminary ruling), Joined cases C-71/11 and C-99/11, 5 September 2012.

83 Ibid., n. 62.

84 Ibid., n. 63.

85 Court of Justice of the European Union, Samira Achbita, Centrum voor gelijkheid van kansen en voor racismebestrijding v. G4S Secure Solutions NV (preliminary ruiling), Case C-157/15, 14 March 2017, n. 17. 
resorted to unconventional expressions such as 'freedom of conscience and religion' ${ }^{86}$ In this sense, the lack of a consistent, unified terminology confirms the complex and diverse nature of the EU laboratory, and the dynamic adaptation to changing contexts of EU institutions, through the flexibility and creativity of their language and concepts. Insofar as this applies to the Court of Justice, it should be reminded here that the jurisdictional dimension of the EU laboratory is even richer, if one considers the dialogue of the Court with the European Court of Human Rights. ${ }^{87}$

At the beginning of this section, I have argued that the EU laboratory offers crucial indications about the place and potential of the formula 'freedom of religion or belief' both a) when the formula is used, and even adopted, and b) when the formula is not used, but documents and actions have an indirect impact on its formulation and use. At the end of the section, it is possible to draw the following conclusions:

a) despite being a latecomer in the adoption of the formula, the EU has emerged as an active, creative interpreter of the formula itself, as well as of the concept and the relevant system of protection and promotion;

b) the EU approach to the formula includes direct (e.g., in the 2013 Guidelines on the protection and promotion of FoRB) and indirect references (e.g., in the dialogue mandated by article 17 TFEU), both categories resulting in a dynamic and adaptable understanding and application of the formula;

c) the direct and indirect EU contribution to the formula confirms and fosters the five features of 'freedom of religion or belief' illustrated above, whereby FoRB: 1) is inclusive of religion and belief and does not isolate any of them;2) is inclusive of both the disjunctive and the conjunctive 'or'; 3 ) is inclusive of religious diversity; 4) is in-

86 Court of Justice of the European Union, Tietosuojavaltuutettu v. Jehovan todistajat uskonnollinen yhdyskunta (preliminary ruling), Case C-25/17, 10 July 2018, n. 46. See also Court of Justice of the European Union, Samira Achbita, Centrum voor gelijkheid van kansen en voor racismebestrijding, cit., n. 27.

87 Besides what has been said earlier about the role of the European Court of Human Rights in the emergence of the formula, especially in the cases of Kokkinakis and Campbell and Cosans, a systematic investigation about the use of the formula in the case law of the Court of Strasbourg is beyond the scope of this work. 
clusive of belief diversity; 5) is inclusive of a diverse articulation of religion, belief, the State, supranational institutions and organisations, and legal systems; 6) is freedom-oriented and rights-oriented in a threefold individual, collective and institutional meaning;

d) through its active and creative interpretation of FoRB, the EU endorses and promotes: 1) the international character of FoRB, in particular with regard to the interaction between the EU, the Council of Europe and the OSCE, the development of a multi-level governance within the EU, and the process of convergence in the use of the formula outside and inside the EU; 2) the necessity of FoRB for sustainable development, and the correlated need, as Ján Figel' says in his 2019 Report, of a shift 'from «FoRB strictu sensu» towards the promotion of the «religious social responsibility»"; $; 8$ and 3 ) the instrumentality of FoRB to manifestation of religion or belief, the status of religion or belief communities and organisations, and the presence and role in society of 'religion or belief' related resources in general and of religion or belief communities and organisations in particular;

e) the EU contribution can be seen as a test for critical views on the formula as conducive to 1) a relativized religion; 2) a binary construction of religion and non-religion no longer in line with contemporary societies, especially in the light of the emergence of the 'unaffiliated' or 'nones'; 3) a vague, all-inclusive and 'impossibly broad' formula, unsuitable for rigorous, effective implementation, especially if belief is not understood as 'something narrower than the general epistemic notion of «belief»’; ${ }^{89}$ and 4) a formula perpetuating a Western, Christian, secular, individualistic, English-speaking neo-imperialism.

In the light of such conclusions about the contribution of the EU laboratory to the formula and its implications, it is now time to move to the final section, where I will lay down research questions aimed at developing the understanding of the formula in view of a better protection and promotion of 'freedom of religion or belief'.

88 Figel' 2019, 6.

89 Expressions between single quotation marks are from Cole Durham, as per our email exchange about this paper in May 2020. 


\section{THE TRANSLATION}

It can be argued that the implementation of the right to freedom of thought, conscience, religion and belief requires the formula 'freedom of religion or belief' not to be challenged. Inquiries aimed at specifying and contextualising the formula, one might think, relativize the underlying concepts and jeopardise the consensus. In this final section I will argue for the contrary. Against the risk of keeping the formula in a bubble, I maintain that the 'freedom of religion or belief' should rather be deepened and explored, including in its controversial aspects. Its meaning and scope ought to be tested and developed, in order for the formula itself to be strengthened, or for alternative formulas to emerge. Key to such process of testing and developing is the production of knowledge on the translation of the formula, linguistic as well as legal, in both the top-down and the bottom-up directions. In fact, the way the formula resonates in languages other than English can make the conversation richer not only with regard to meanings and nuances conveyed through other languages, but also with regard to what non-English native speakers might have in their mind and heart when they employ the formula in English.

In one of his 2019 recommendations, Special Envoy Ján Figel' encourages 'partnerships between academia, CSO and religious actors to join forces and work on the «translation» of the FoRB/HR language into the local language, incorporating local values, knowledge and practices'. As illustrated in the previous section, the European Union is a unique laboratory in which this recommendation can be developed into an unprecedented conversation on the top-down and bottom-up translation of rights and freedoms pertaining to religion or belief.

Crucial for the translation process, and the development of the formula are ten sets of questions to be addressed from within each of the Member States of the European Union. The ten sets of questions are built around ten frames of reference for the elaboration of FoRB and the related language and concepts in the European Union: 1) the 2013 EU Guidelines and the EU action on FoRB outside the EU; 2) the foreign action of EU Member States; 3) EU human rights law, and its connections with the international protection and promotion of freedom of religion or belief in the context of the United Nations, the Organisation for Security and Coop- 
eration in Europe and the Council of Europe; 4) EU and EU Member States anti-discrimination law; 5) EU law and policy directly or indirectly related to religion or belief within the EU; 6) constitutional law of EU Member States; 7) domestic law and policy of EU Member States on the status of churches and religious associations or communities and philosophical and non-confessional organisations; 8) domestic legal scholarship; 9) domestic non-legal scholarship; 10) actors' discourse and documents.

The ten sets of questions can be formulated as follows.

a) The first set of questions concerns the formula and the $2013 \mathrm{EU}$ Guidelines on FoRB and more generally the EU action on FoRB outside the EU. If a translation of the 2013 EU Guidelines on FoRB in the language/s of the relevant Member State is available, how is the formula translated? And is the translation official or unofficial (e.g., the official version in French provided by the European $\mathrm{Union}^{90}$ )? If the $2013 \mathrm{EU}$ Guidelines on FoRB are indeed available in the language/s of the Member State, does the translation of the formula correspond to the translation of the formula in the Recommendation to the Council of 13 June 2013 on the draft EU Guidelines on the Promotion and Protection of Freedom of Religion or Belief? Beyond the 2013 Guidelines, how are references to the formula in the EU action on FoRB outside the EU (e.g., the action of the EU Special Envoy between 2016 and 2019) translated in the language/s of the relevant Member State? Are translations of the formula consistent with the translation of the 2013 Guidelines, and with one another?

b) The second set of questions pertains to the formula and the foreign action of EU Member States. In case the government has organised an office and/or appointed an individual Envoy/Ambassador for the international protection and promotion of freedom of religion or belief, is the formula 'freedom of religion or belief' adopted, and how is it translated? If not, which alternative formula/s is/are used, with which conceptual, political and legal implications (e.g., Denmark has a special representative for 'freedom of religion or belief',

90 See http://data.consilium.europa.eu/doc/document/ST-11491-2013-INIT/fr/pdf (last visited 1 July 2020). 
whereas Poland has a special envoy for 'religious freedom': how do these formulas translate in Danish and Polish, and are they consistently used in the foreign action of the relevant countries)? Has there been a chronological evolution of the terminology in the country's language/s since the US International Religious Freedom Act of 1998 and the EU Guidelines on FoRB of 2013?

c) The third set regards the formula in EU human rights law, and its connections with the international protection and promotion of freedom of religion or belief in the context of the United Nations, the Organisation for Security and Cooperation in Europe and the Council of Europe. ${ }^{91}$ Is the formula translated consistently in documents issued by the different institutions? In case of variations, is it possible to identify patterns and trends (e.g., the official translation in Spanish by the Ministry of Justice of the 2013 OSCE/ODIHR 'Guidelines on the Legal Personality of Religious or Belief Community' has 'Directrices sobre la personalidad jurídica de las comunidades religiosas o de creencias', ${ }^{92}$ whereas the official Spanish version of article 10 of the EU Charter of Fundamental Rights has 'de religión o de convicciones' for 'religion or belief'; are 'creencias' and 'convicciones' simply interchangeable?).

d) The fourth set is concerned with the formula in EU anti-discrimination law and in the anti-discrimination law of EU Member States. How is the expression 'religion or belief' in the EU treaties (e.g., article 19 TFEU) and EU anti-discrimination law (e.g., article 4 n. 2 Council Directive 2000/78/EC on employment) translated in the language/s of the relevant EU Member State? Are official translations of EU documents, and related cases decided by the Court of Justice of the European Union consistent? Or is the same expression 'religion or belief' translated with different terms in the language/s of the EU Member State, possibly with variations over time?

91 For the United Nations, see in particular the Universal Declaration of Human Rights Translation Project at https://www.ohchr.org/EN/UDHR/Pages/Introduction.aspx (last visited 1 July 2020). The ICCPR is available in Arabic, Chinese, French, Russian and Spanish (https://www.ohchr.org/en/professionalinterest/pages/ccpr.aspx; last visited 1 July 2020).

92 See the 2018 document at https://www.osce.org/es/odihr/401690?download=true (last visited 1 July 2020). 
Are translations consistent with the translation of 'religion or belief' in the formula 'freedom of religion or belief' under a) and b)? Beyond EU anti-discrimination law, does domestic anti-discrimination law refer to other concepts and expressions, somehow associated with religion or belief?

e) The fifth set of questions relates to the formula as directly or indirectly referred to in EU law or policy documents, this including, amongst others, provisions on religion or belief (e.g., article 17 TFEU), data protection law (e.g., article 91 of the 2016 General Data Protection Regulation 2016/679) and refugee law (e.g. article 10, section 1 (b) Council Directive 2011/95/EU)? How are the relevant expressions translated in the language/s of the EU Member State, and how consistently with the translations of the relevant English versions?

f) The sixth set regards the formula in the constitutional law of EU Member States. How does the terminology under a) and b) relate to the language and concept of the pertinent constitutional law? Does the formula exist in the constitution? Which would be a correspondent expression, and how would it differ from the formula? Can the terms 'thought', 'conscience', 'religion' and 'belief', or other pertinent terms be located in the constitution? Have there been changes in the terminology in successive constitutions? Can any antecedent predating 1948 be identified, somehow anticipating the language of article 18 UDHR?

g) The seventh set of questions concerns the formula in domestic law and policy of EU Member States on the status of churches and religious associations or communities and philosophical and non-confessional organisations. Apart from d) and f), is the formula used in domestic legal or policy documents, including court decisions? Are alternative formulas used? Is the terminology consistent from one occurrence to another?

h) The eighth set of questions regards the formula in domestic legal scholarship. Has the formula been used, or adopted, by scholars, and with which degree of consistency in the translation? Are other somehow correspondent formulas employed, or even preferred? Can some trend be identified? Has the formula itself ever been discussed (e.g., would 'przekonania' in Polish be somehow associated 
with Marxist-Leninist doctrine)? Are there scholars or other commentators who object to the formula and its implications, possibly in the name of its inconsistency with the local constitutional tradition (e.g., Thomas Farr in the US ${ }^{93}$ )?

i) The ninth set of questions concerns the formula in domestic non-legal scholarship, especially in social sciences. Again, as for the set under h), has the formula been used, or adopted, by scholars, and with which degree of consistency in the translation? Are other somehow correspondent formulas employed, or even preferred? Can some trend be identified?

1) The tenth set of questions regards the formula in actors' discourse and documents. Is the formula adopted by actors in EU Member States, by whom and in which translation? Is it possible to identify actors, including religion or belief communities which clearly adopt or do not adopt the formula? Are other somehow correspondent formulas employed, or even preferred? Can some trend be identified? How much is produced in English and does not get translated (e.g., the Danish Report on the international protection of FoRB of $\left.2019^{94}\right)$ ?

By addressing these questions, and further investigating the substance of linguistic variations and their intended or unintended meaning, it could be possible to advance not only in knowledge, but also in action, with respect to three key aspects of the emergence of the formula 'freedom of religion or belief': 1) the degree and ways in which the formula is adopted, and its consequent top-down impact in the relevant EU Member State; 2 ) the variations of the formula and/or the alternative formulas resorted to in the relevant EU Member State; 3) the resulting creative appropriation and/or rejection of the formula. A methodology of 'Law and Corpus Linguistics', of the kind experimented at Brigham Young Univer-

93 I refer in particular to Farr 2015, 23-39.

94 See Peterson, and Marshall 2019. The Report was not translated in Danish, but anticipated by a Danish shorter and different version. See 'Religionsfrihed for alle' (København: Institut for Menneskerettigheder. Danmarks Nationale Menneskerettighedsinstitution, 2015) at https://menneskeret.dk/files/media/dokumenter/udgivelser/religionsfrihed_for_alle_marie_juul_2015.pdf (last visited 1 July 2020). My thanks to Marie Juul Petersen for the information and clarification. 
sity, might enhance the investigation in both a quantitative and qualitative perspective. ${ }^{95}$

My hypothesis, at this final stage, is that a stronger and deeper knowledge about the top-down impact and its appropriation, reinvention or rejection at the bottom level would provide a significant test for the formula, and would empower actors to make their future choices, starting from a more informed use of the language/s. Were the formula to resist the stress test, we could say it has been strengthened. Otherwise, the exercise would have exposed the weakness of an overly top-down project.

\section{CONCLUSION}

In this article I have offered 1) an attempt through some objective references to draw the chronology and sources, documentary and institutional, of the emergence of the formula 'freedom of religion or belief' in the post-1948 international context; 2) a hypothesis about the most significant features of the formula, and their crucial role in making the formula emerge, and somehow succeed, at the UN, OSCE and EU level; 3 ) a mapping of the formula in the EU context and an interpretation of the EU as a laboratory where the formula is appropriated, reinvented and challenged in a variety of ways (direct and indirect, intentional and unintentional), also depending on the different linguistic versions in EU Member States; and 4) a set of questions related to the linguistic and legal translation of the formula in EU Member States with the aim of improving knowledge on the formula in both its top-down and bottom-up dynamic unfolding.

95 See https://lcl.byu.edu/projects/law-corpus-linguistics-background/ (last visited 1 July 2020) . As explained in the introduction to the BYU project, 'Corpus linguistics is an approach to language research that utilizes a principled collection of texts (i.e., a corpus) in order to better understand patterns of language use. Analysis of these patterns can produce insight into, among other things, the meaning of words and phrases. Linguists (and lexicographers) have long understood that corpora are a vastly superior guide to interpretation than native speaker intuition or even dictionaries. With advances in computer technology, the use of corpus linguistics for research has expanded dramatically. Legal scholars and judges have only recently begun to tap the potential of this method because most are unaware of its possibilities'. Reference given: Biber, Conrad, and Reppen 1998. 
Resonating the invitation by Ján Figel' to 'work on the «translation» of the FoRB/HR language into the local language, incorporating local values, knowledge and practices', the Report on the international protection of FoRB presented in 2019 by the Danish Institute for Human Rights recommends that interventions for the international promotion of freedom of religion or belief 'should have strong local anchorage'. ${ }^{96}$ This should include, the Report reads, 'broader efforts to strengthen the local legitimacy of FoRB, e.g. through processes of «vernacularisation»' ${ }^{97}$ For the sake of universality and consistency, the future success of the formula, or of better alternative formulas, seems to depend on a high-level, harmonising and structuring of its contents and in a sophisticated, international top-down action, matched with bottom level proactive creative interpretation. The challenge rests in the possibility of a translation that strengthens and does not undermine a truly universal conversation and promotion of the "freedom of religion or belief', ${ }^{98}$

Because of the dynamic tension between FoRB outside and FoRB inside the EU and between divergence of Member States inside the EU and convergence outside the EU, ${ }^{99}$ the European Union represents a unique test and opportunity for the possibility to seriously and meaningfully 'translate' freedom of religion or belief in different languages, and contexts.

\section{REFERENCES}

Angeletti, Silvia. 2008. Libertà religiosa e Patto internazionale sui diritti civili e politici. Torino: Giappichelli.

Annicchino, Pasquale. 2013. 'Religion and EU Institutions'. Ecclesiastical Law Journal, 15/3: 326-331.

96 Peterson, and Marshall 2019, 72.

97 Ibid.

98 A similar challenge concerns the global conversation around human dignity and human rights. For its implications for the advancement of freedom of religion or belief, see the Punta del Este Declaration on Human Dignity for Everyone Everywhere, signed on 4 December 2018 (https://www.dignityforeveryone.org/introduction/; last visited 1 July 2020).

99 I presented patterns of European convergence and divergence in law and religion in general and freedom of religion or belief in particular in Ventura 2015, 89-102. 
Annicchino, Pasquale. 2015. Esportare la libertà religiosa. Il modello americano nell'arena globale. Bologna: il Mulino.

Annicchino, Pasquale. 2017. Law and International Religious Freedom. The Rise and Decline of the American Model. Abingdon: Routledge.

Annicchino, Pasquale. 2020. 'The European Union Special Envoy on Freedom of Religion or Belief: an Assessment'. The Review of Faith and International Affairs, 18/2: 76-79.

Austin, John Langshaw. 1962. How to Do Things with Words. Oxford: Oxford University Press.

Balazka, Dominik. 2020. Mapping Religious Nones in the World (Report of the Centre for Religious Studies at Fondazione Bruno Kessler, Trento); https:// isr.fbk.eu/en/report-mapping-religion-nones-in-the-world-2020/

Barberini, Giovanni. 2004. Sicurezza e cooperazione da Vancouver a Vladivostock: introduzione allo studio dell'Organizzazione per la sicurezza e la cooperazione in Europa. Torino: Giappichelli.

Biber, Douglas, Susan Conrad, and Randi Reppen. 1998. Corpus Linguistics: Investigating Language Structure and Use. Cambridge: Cambridge University Press.

Bielefeldt, Heiner, Nazila Ghanea, and Michael Wiener. 2016. Freedom of Religion or Belief. An International Law Commentary. Oxford: Oxford University Press.

Bielefeldt, Heiner, and Michael Wiener. 2019. Religious Freedom Under Scrutiny. Philadelphia: University of Pennsylvania Press.

Boyle, Kevin, and Juliet Sheen (eds.). 1997. Freedom of Religion and Belief: A World Report. London: Routledge.

Carrera, Sergio, Elspeth Guild, Lina Vosyliute, and Petra Bárd. 2017. Towards a Comprehensive EU Protection System for Minorities; https://www.ceps.eu/ ceps-publications/towards-comprehensive-eu-protection-system-minorities/

Colombo, Federico. 2020. 'Interpreting Article 17 TFEU: New Openings towards a European Law and religion System'. Rivista telematica Statoechiese, 1: $1-31$.

DeGirolami, Marc O. 2013. The Tragedy of Religious Freedom. Cambridge MA: Harvard University Press.

Diotallevi, Luca. 2010. Una alternativa alla laicità. Soveria Mannelli: Rubbettino.

Dubuisson, Daniel. 2020. L'invention des religions. Paris: CNRS.

Durham, W. Cole. 1999. Freedom of Religion or Belief: Laws Affecting the Structuring of Religious Communities; https://www.osce.org/files/f/documents /4/7/16698.html.

Durham, W. Cole, Tore S. Lindholm, and Bahia G. Tahzib-Lie (eds.). 2004. Facilitating Freedom of Religion or Belief. A Deskbook. Leiden: Brill. 
Durham, W. Cole, and Brett Sharffs. 2010. Law and Religion: National, International, and Comparative Perspectives. New York: Aspen Publishers.

Croce, Mariano. 2012. Self-sufficiency of Law. A Critical-institutional Theory of Social Order. Dordrecht - Heidelberg - New York - London: Springer.

Farr, Thomas F. 2015. 'A Global Crisis of Religious Liberty: Evidence, Origins, and Singificance'. In: La libertà religiosa secondo il diritto internazionale e il conflitto globale dei valori. International religious freedom and the global clash of values, ed. by Monica Lugato, 23-39. Torino: Giappichelli.

Ferlan, Claudio, and Marco Ventura. 2018. 'Introduction'. Annali dell'Istituto Italo-Germanico di Trento, 44/2: 15-18.

Ferrari, Daniele. 2019. Il concetto di minoranza religiosa dal dritto internazionale al diritto europeo. Bologna: il Mulino.

Ferrari, Silvio, W. Cole Durham, and Elisabeth A. Sewell (eds.). 2003. Law and Religion in Post-Communist Europe. Leuven: Peeters.

Figel', Ján. 2019. Report The mandate of the Special Envoy for the promotion of freedom of religion or belief outside the European Union: activities and recommendations (May 2016-November 2019), 21 November, p. 3 (https://7c1d8c8f6bcf-4657-9598-a27b0c95bd02.filesusr.com/ugd/7dce12_6da28c56290944 24bdd18cc9961d3f91.pdf).

Gunn, T. Jeremy. 2004. 'The United States and the Promotion of Freedom of Religion and Belief'. In Facilitating Freedom of Religion or Belief. A Deskbook, ed. by W. Cole Durham, Tore S. Lindholm, and Bahia G. Tahzib-Lie, 721-746. Leiden: Brill.

Krishnaswami, Arcot. 1960. Study of discrimination in the matter of religious rights and practices. New York: United Nations.

Lindqvist, Linde. 2017. Religious Freedom and the Universal Declaration of Human Rights. Cambridge: Cambridge University Press.

Massignon, Bérengère. 2007. Des dieux et des fonctionnaires. Religions et laïcités face au défi de la construction européenne. Rennes: Presses Universitaires de Rennes.

Messner, Francis (ed.). 2010. Dictionnaire du droit des religions. Paris: Ed. du CNRS. Perchoc, Philippe. 2017. Religion and the EU's external policies. Increasing engagement: in-depth analysis. Brussels: European Parliamentary Research Service.

Petersen, Marie Juul and Katherine Marshall. 2019. International Promotion of Freedom of Religion or Belief. Sketching the Contours of a Common Framework. Copenhagen: The Danish Institute for Human Rights.

Petito, Fabio, Stephanie Berry, and Maria Mancinelli. 2018. Interreligious Engagement Strategies: A Policy Tool to Advance Freedom of Religion or Belief. Sussex: FORB \& Foreign Policy Initiative, Sussex University. 
Rappaport, Roy. 1999. Ritual and Religion in the Making of Humanity. Cambridge: Cambridge University Press.

Schouppe, Jean-Pierre. 2015. La dimension institutionnelle de la liberté de religion dans la jurisprudence de la Cour européenne des droits de l'homme. Paris: Pedone.

Su, Anna. 2016. Exporting Freedom. Religious Liberty and American Power. Cambridge MA: Harvard University Press.

Sullivan, Winnifred F. 2018. The Impossibility of Religious Freedom. Princeton NJ: Princeton University Press.

Tahzib, Bahia G. 1996. Freedom of Religion or Belief. Ensuring Effective International Legal Protection. The Hague - London: Martinus Nijhoff Publishers.

van der Vyver, Johan D., and John Witte Jr. (eds.). 1996. Religious Human Rights in Global Perspective. The Hague: Martinus Nijhoff.

Ventura, Marco. 1999. 'Diritto e religione in Europa: il laboratorio comunitario'. Politica del diritto 30/4: 577-628.

Ventura, Marco. 2001. La laicità dell'Unione europea. Torino: Giappichelli.

Ventura, Marco. 2010. 'The Changing Civil Religion of Secular Europe'. The George Washington International Law Review, 41/4: 947-961.

Ventura, Marco. 2014a. From Your Gods to Our Gods. A History of Religion in Indian, South African and British Courts. Eugene OR: Cascade Books.

Ventura, Marco. 2014b. 'L'articolo 17 TFUE come fondamento del diritto e della politica ecclesiastica dell'Unione europea'. Quaderni di diritto e politica ecclesiastica, 22/2: 293-304.

Ventura, Marco. 2015. 'Balancing convergence and divergence. The challenge for European law and religion'. In: La libertà religiosa secondo il diritto internazionale e il conflitto globale dei valori. International religious freedom and the global clash of values, ed. by Monica Lugato, 89-102. Torino: Giappichelli.

Ventura, Marco. 2018. '«Io combatto l'analfabetismo religioso»'. Corriere della Sera-La Lettura, 13 May.

Ventura, Marco. 2019a. 'Religione - credo'. Gnosis. Rivista italiana di intelligence, 4: 134-145.

Ventura, Marco. 2019b. 'Non discrimination and protection of diversity and minorities'. In: The History of the European Union. Constructing Utopia, ed. by Gugliano Amato, Enzo Moavero-Milanesi, Gianfranco Pasquino, and Lucrezia Reichlin, 239-255. Oxford: Hart Publishing.

Ventura, Marco. 2020. 'Fede fai-da-te'. Corriere della Sera-La Lettura, 11 October. 
Table 1. Freedom of Religion or Belief. A timeline of significant steps in the international emergence of the formula from a European perspective

\begin{tabular}{|c|c|}
\hline 1948 & $\begin{array}{l}\text { Universal Declaration of Human Rights: art. } 18 \text { refers to 'freedom of thought, con- } \\
\text { science and religion' and to freedom to change/manifest 'religion or belief'. }\end{array}$ \\
\hline 1950 & $\begin{array}{l}\text { European Convention on Human Rights: art. } 9 \text { refers to 'freedom of tought, conscience } \\
\text { and religion' and to freedom to change/manifest 'religion or belief'. }\end{array}$ \\
\hline 1952 & $\begin{array}{l}\text { Protocol to the European Convention on Human Rights: art. } 2 \text { protects 'the right of } \\
\text { parents to ensure (...) education and teaching in conformity with their own religious } \\
\text { and philosophical convictions'. }\end{array}$ \\
\hline 1960 & $\begin{array}{l}\text { Arcot Khrishnaswami produces for the United Nations a 'Study of discrimination in } \\
\text { the matter of religious rights and practices'. The 'term «religion or belief» is used to } \\
\text { include, in addition to various theistic creeds, such other beliefs as agnosticism, free } \\
\text { thought, atheism and rationalism'. }\end{array}$ \\
\hline 1966 & International Covenant on Civil and Political Rights: art. 18 refers to 'religion or belief'. \\
\hline 1975 & $\begin{array}{l}\text { Helsinki Declaration (Final Act) of 1975: principle VII, para. } 1 \text { refers to 'freedom of } \\
\text { thought, conscience, religion or belief'. }\end{array}$ \\
\hline 1981 & $\begin{array}{l}\text { UN Declaration on the Elimination of All Forms of Intolerance and of Discrimination } \\
\text { based on Religion or Belief: the preamble and art. } 5 \text { refer to 'freedom of religion or } \\
\text { belief'. }\end{array}$ \\
\hline 1982 & $\begin{array}{l}\text { European Court of Human Rights, case Campbell and Cosans: the word 'convictions' } \\
\text { of the Protocol to the European Convention on Human Rights is 'akin to the term be- } \\
\text { liefs appearing in article } 9(\ldots) \text { and denotes views that attain a certain level of cogency, } \\
\text { seriousness, cohesion and importance'. }\end{array}$ \\
\hline 1986 & UN Special Rapporteur on Religious Intolerance. \\
\hline 1992 & $\begin{array}{l}\text { UN Declaration on the Rights of Persons Belonging to National or Ethnic, Religious } \\
\text { and Linguistic Minorities. }\end{array}$ \\
\hline 1993 & $\begin{array}{l}\text { European Court of Human Rights, case Kokkinakis: 'freedom of thought, conscience } \\
\text { and religion' is 'in its religious dimension, one of the most vital elements that go to } \\
\text { make up the identity of believers and their conception of life, but it is also a precious } \\
\text { asset for atheists, agnostics, sceptics and the unconcerned'. }\end{array}$ \\
\hline 1998 & US International Religious Freedom Act 1998. \\
\hline 1999 & $\begin{array}{l}\text { OSCE/ODIHR background paper by Cole Durham on 'Freedom of Religion or Belief: } \\
\text { Laws Affecting the Structuring of Religious Communities'. }\end{array}$ \\
\hline \multirow[t]{2}{*}{2000} & $\begin{array}{l}\text { UN Special Rapporteur on Freedom of Religion or Belief (name of the mandate } \\
\text { changed from previous 'UN Special Rapporteur on Religious Intolerance'). }\end{array}$ \\
\hline & EU Charter of fundamental rights: art. 10 and art. 21 refer to 'religion or belief' \\
\hline 2004 & OSCE/ODIHR Guidelines for Review of Legislation Pertaining to Religion or Belief. \\
\hline 2013 & EU Guidelines on the Protection and Promotion of Freedom of Religion or Belief. \\
\hline 2014 & OSCE/ODIHR Guidelines on the Legal Personality of Religious or Belief Communities. \\
\hline 2019 & OSCE/ODIHR Freedom of Religion or Belief and Security. Policy Guidance. \\
\hline
\end{tabular}


Table 2. Freedom of Religion or Belief in the European Union. A timeline of significant steps in the emergence of the formula

\begin{tabular}{|c|c|}
\hline 1975 & $\begin{array}{l}\text { ourt of Justice of the European Communities, case Prais: 'freedom of religion' as en- } \\
\text { rined in art. } 9 \text { European Convention on Human Rights is acknowledged as forming } \\
\text { rt of the fundamental rights recognized in Community law. }\end{array}$ \\
\hline 1988 & $\begin{array}{l}\text { ourt of Justice of the European Communities, case Steymann: reference to 'commu- } \\
\text { ties based on religion or on another form of philosophy'. }\end{array}$ \\
\hline 1992 & $\begin{array}{l}\text { Maastricht Treaty: according to art. F fundamental rights as protected in the European } \\
\text { Convention on Human Rights and in the constitutional traditions are general princi- } \\
\text { ples of Community law. Implicit refererence to 'religion or belief' as mentioned in art. } \\
9 \text { of the European Convention on Human Rights. }\end{array}$ \\
\hline \multirow[t]{2}{*}{1997} & $\begin{array}{l}\text { Treaty of Amsterdam: art. } 2 \mathrm{n} .7 \text { (introducing art. } 6 \mathrm{a} \text { in the Treaty establishing the } \\
\text { European Community) prohibits discrimination based on 'religion or belief'. }\end{array}$ \\
\hline & ociations or commu \\
\hline \multirow[t]{2}{*}{2000} & Charte \\
\hline & $\begin{array}{l}\text { Directive } 2000 / 78 / \mathrm{EC} \text { on equal treatment in employment: art. } 1 \text { prohibits discrimina- } \\
\text { tion based on 'religion or belief'. Art. } 4 \mathrm{n} .2 \text { mentions 'churches and other public or } \\
\text { private organisations the ethos of which is based on religion or belief'. }\end{array}$ \\
\hline \multirow[t]{2}{*}{2004} & $\begin{array}{l}\text { Directive 2004/83/EC on the refugees' status: art. 10, section } 1 \text { (b) defines 'the con- } \\
\text { cept of religion' as including both 'religious' and 'non-religious' 'beliefs'. }\end{array}$ \\
\hline & ent and regular dialogue' \\
\hline 2007 & $\begin{array}{l}\text { eaty of Lisbon: art. } 17 \text { of the Treaty on the functioning of the European Unon refers } \\
\text { both 'churches and religious associations or communities' and 'philosophical and } \\
\text { n-confessional organisations' and provides for an 'open, transparent and regular } \\
\text { logue' with them. Art. } 19 \text { refers to 'religion or belief'. }\end{array}$ \\
\hline 2011 & $\begin{array}{l}\text { fugees' status confirms the reference of the } 2004 \text { Di- } \\
\text { ion' as including both 'religious' and 'non religious' }\end{array}$ \\
\hline \multirow[t]{3}{*}{2013} & Guidelines on Freedom of Religion or Belief. \\
\hline & $\begin{array}{l}\text { Decision of the European Ombudsman in his inquiry into complaint 2097/2011/ } \\
\text { RA against the European Commission about the dialogue with philosophical and } \\
\text { non-confessional organisations. }\end{array}$ \\
\hline & \\
\hline 2014 & $\begin{array}{l}\text { Foundation of the European Parliament Intergroup on Freedom of Religion or Belief } \\
\text { and Religious Tolerance. }\end{array}$ \\
\hline 2016 & the office of Special Envoy for the promotion of freedom o \\
\hline
\end{tabular}




\begin{tabular}{|l|l|}
\hline 2018 & $\begin{array}{l}\text { Direct applicability of the General Data Protection Regulation 2016/679: art. } 91 \text { refers } \\
\text { to 'churches and religious associations or communities' and not to philosophical and } \\
\text { non-confessional organisations. }\end{array}$ \\
\cline { 2 - 3 } & $\begin{array}{l}\text { Court of Justice of the European Communities, case Egenberger: Directive 2000/78 } \\
\text { is to ensure a 'fair balance between the right of autonomy of churches and other or- } \\
\text { ganisations whose ethos is based on religion or belief, on the one hand, and, on the } \\
\text { other hand, the right of workers, inter alia when they are being recruited, not to be } \\
\text { discriminated against on grounds of religion or belief, in situations where those rights } \\
\text { may clash'. }\end{array}$ \\
\hline 2019 & $\begin{array}{l}\text { European External Action Service: launch of the programme on Global exchange on } \\
\text { religion in society. }\end{array}$ \\
\cline { 2 - 2 } & $\begin{array}{l}\text { End of mandate Report of the Special Envoy for the promotion of fredom of religion } \\
\text { or belief outside the EU: five recommendations about going beyond 'freedom of reli- } \\
\text { gion or belief' sensu stricto. }\end{array}$ \\
\hline
\end{tabular}

\section{FORMUŁA „WOLNOŚĆ RELIGII LUB PRZEKONAŃ” W LABORATORIUM UNII EUROPEJSKIEJ}

Streszczenie

W artykule argumentuje się, że głębsza i lepsza wiedza na temat stosowanych w przeszłości i obecnie użyć formuły „wolność religii lub przekonań” może zaowocować większą spójnością pomiędzy stosowaną terminologią a odpowiadającymi jej ideami, przyczyniając się również do ubogacenia debaty prowadzonej na poziomie krajowym i międzynarodowym na temat ochrony i promocji praw i wolności odnoszących się do „religii lub przekonań”. W pierwszej części (The emergence - Geneza) Autor zarysowuje genezę i kontekst pierwszych zastosowań omawianej formuły. Potwierdzając znaczenie Narodów Zjednoczonych podkreśla, że związane z tym dokumenty powstałe w ramach Organizacji Narodów Zjednoczonych nie były ani jedynymi ani nie funkcjonowały w oderwaniu od innych. Akcentuje w szczególności rolę Konferencji (obecnie: Organizacji) Bezpieczeństwa i Współpracy w Europie oraz znaczenie szerszej dyskusji na poziomie międzynarodowym, która nabrała przyspieszenia po roku 1988, kiedy to przyjęto amerykańską ustawę o wolności religijnej w stosunkach międzynarodowych (International Religious Freedom Act). W części drugiej (The features - Cechy) omówione są najważniejsze cechy tytułowej formuły. Zwraca się uwagę, że cechy te wyjaśniają sukces, który formuła ta odniosła na poziomie ONZ i OBWE oraz Unii Europejskiej (przede wszystkim w jej działaniach zewnętrznych). W części 
trzeciej (The EU laboratory - Laboratorium Unii Europejskiej) omawia się stosowanie określenia „wolność religii lub przekonan” w kontekście unijnym. Unia Europejska jest przy tym postrzegana jako laboratorium, w którym formułę tę przyjęto, poddano weryfikacji jej użyteczność i na różne sposoby przedefiniowano. W części czwartej i ostatniej (The Translation - Tłumaczenie) formułuje się dziesięć zestawów pytań dotyczących językowych i prawnych aspektów tłumaczenia omawianej formuły w państwach członkowskich UE. Autor twierdzi, że odpowiedź na nie może się znacząco przyczynić do lepszego zrozumienia omawianej formuły w dwojakim - oddolnym i odgórnym - ujęciu dynamicznym, dostarczając w ten sposób potrzebnych narzędzi naukowcom i innym osobom, których zadaniem jest połączenie globalnego potencjału tej formuły w języku angielskim z jej wariantami w różnych językach i kulturach.

Słowa kluczowe: wolność religii lub przekonań; relacje Kościół - Państwo; prawo i religia; prawo Unii Europejskiej; międzynarodowe prawo praw człowieka

Ttumaczenie: Daria Bębeniec 
